\title{
Analyst Behavior and Underwriter Choice
}

\author{
Walter I. Boudry, Leonard N. Stern School of Business, New York University \\ Jarl G. Kallberg, Thunderbird School of Global Management \\ Crocker H. Liu, School of Hotel Administration, Cornell University
}

\begin{abstract}
We examine the role that analysts play in a firm's choice of underwriter using a sample of major U.S. investment banks. In order to best capture the competitive environment, which is critical to the potential role that analysts play, we limit our sample of firms to 161 real estate investment trusts (REITs) issuing debt or equity between 1996 and 2004. Using the estimation technique of Ljungqvist et al. (Journal of Finance 61:301-340 2006), which accounts for the endogeneity of analyst behavior and the coverage self-selection decision, we find that target prices that are optimistic relative to competitors' target prices, significantly increase an underwriter's probability of attracting underwriting business. This result holds for both equity and debt issues with fees greater than one million dollars. We also find evidence consistent with the notion that increased regulatory scrutiny of conflicts of interest between analysts and investment banks has decreased the impact of analyst behavior on underwriter choice.
\end{abstract}

\section{Introduction}

There has been a great deal of recent interest in how firms select a particular underwriter for an issue. The decision is complex because potential underwriters vary along several important dimensions: reputation, industry expertise, analyst coverage, fee structure, etc. In the wake of the Global Settlement between Wall Street's ten largest underwriters and the New York Attorney General Eliot Spitzer, the SEC and other Federal and State regulators, the possibility that overly optimistic analysts can attract deal flow has come under increased scrutiny. ${ }^{1}$ However, this regulatory shift has been spurred more by high profile examples of conflicts of interest rather than empirical fact. ${ }^{2}$ Recent empirical analysis of this issue has provided no consistent evidence suggesting that analysts use overly optimistic recommendations to garner underwriting business. While Ellis et al. (2005) find a positive relationship between analyst recommendations and deal flow, they treat analyst coverage as exogenous. Ljungqvist

\footnotetext{
${ }^{1}$ See the SEC's web page, http://www.sec.gov/news/press/2003-54.htm, for details.

${ }^{2}$ See Cole (2001) and Gasparino (2005) for a discussion of some high profile cases.
} 
et al. (2006) rectify this potential flaw and find that a weak or potentially negative relationship exists between analyst behavior and underwriting activity.

We examine how analysts potentially influence a firm's choice of underwriter using a sample of all major U.S. investment banks; however we constrain this sample to those banks that were involved in the underwriting of REIT securities over the period 1996 to 2004. While this restriction has some obvious drawbacks, we believe our sample provides an excellent setting in which to examine this relation for three major reasons. First, for this sample of firms we are able to obtain both recommendations and target price data for analysts covering the firms. Brav and Lehavy (2003) and Asquith et al. (2005) show that analysts' target prices contain information incremental to that provided in analysts' recommendations. Examining target prices rather than just recommendations, as in the previous literature, gives this study potentially greater power to detect any role that analyst behavior plays in attracting underwriting business.

Second, REITs provide a sample where the competing forces driving underwriter choice are likely to be particularly strong. REITs are required to pay out at least $90 \%$ of their taxable income as dividends. ${ }^{3}$ As a result, internal financing is not a viable source of funds for new investment, and due to the capital-intensive nature of the real estate industry, REITs come to market to raise new capital far more frequently than regular firms. In our sample, the average time between issuances is 442 days, with $62 \%$ of firms coming to market within a year of their last issuance. A REIT's greater need for frequent access to external capital markets provides an environment in which existing incumbent relationships are likely to be very strong. That is, the firm-specific capital that an underwriter (or lender) develops through past deals with the firm is far more likely to be relevant when the last issue was relatively recent. This implies that past relationships should be a major determinant of underwriter choice. In addition, the frequency with which REITs come to market also makes them attractive from the underwriter's perspective. If there is some value to incumbency and to providing favorable coverage to win one deal, the underwriter has potential to gain from a sequence of future deals.

The third possible advantage of our sample is that by restricting our analysis to investment banks that underwrite REIT deals we can obtain a more precise determination of which banks are actually competing for particular deals. An examination of the deals in our sample shows that general underwriting relationships can be quite misleading at the industry level. For example, in aggregate J.P Morgan is considered a highly reputable underwriter and in the Ljungqvist et al. (2006) study would be considered to be competing for every deal that came to market. However, in our industry specific

\footnotetext{
${ }^{3}$ See Kallberg et al. (2003) and Boudry (2010) for a discussion of the payout policy of REITs.
} 
sample, J.P Morgan is a dominant debt underwriter capturing 10-20\% market share annually, yet underwrote very few equity deals. ${ }^{4}$ Since bank competition for deals is the focus of our study, paying particular attention to the underwriting landscape at the industry level should improve the power of our tests.

Our restriction to only REIT deals (in addition to the obvious decrease in sample size) will be suspect only if one assumes that the investment banks treat REIT transactions differently from other deals. There is no obvious reason for this given that the focus of our analysis is on the fundamental firmunderwriter relationship. This relationship is identical to that of a typical firm. The underwriters in the REIT market are the same underwriters active for regular firms, the size of the deals coming to market are comparable to those used in other studies, and the fee structure is similar. ${ }^{5}$

We use the estimation approach of Ljungqvist et al. (2006). This methodology accounts for the endogeneity of analyst behavior and the self-selection decision of whether or not an analyst chooses to cover a firm. We find target prices that are optimistic relative to competitors' target prices significantly increase an underwriter's probability of underwriting an issue. This result holds for both equity and debt issues when fees are greater than $\$ 1$ million. As a robustness check, using a recommendations-based measure of analyst optimism, we find a significantly positive relationship only for debt issues. Of course, as in any empirical analysis, the unique characteristics of our sample can contribute to these results.

Our study contributes to the literature in three major ways. First, as noted earlier, there is still no convincing empirical evidence that analysts can use their recommendations to attract potential underwriting clients. Studies using recommendations, such as Ljungqvist et al. (2006) and Clarke et al. (2007), find no or possibly a negative relationship between analyst behavior and underwriter choice. The results of this paper indicate that this result may be a function of the coarseness of the measure of analyst behavior employed since our tests using recommendations rather than prices are statistically weaker.

Second, our evidence suggests that increased regulatory scrutiny of potential conflicts of interest between analysts and investment banks has led to a decrease in the impact of analyst behavior on underwriter choice. Examining deals before and after 2001, the coefficient on analyst behavior for equity deals post 2001 is half the size of the coefficient in the pre 2001 sample. $^{6}$

\footnotetext{
${ }^{4}$ J.P Morgan had an equity market share of 2.7\% in 2004, but underwrote no equity deals from 1999 to 2003.

${ }^{5}$ In our sample the average seasoned equity issuance is $\$ 90$ million and the average debt issuance is $\$ 100$ million. These are slightly smaller than the averages for similar issuances reported in Ljungqvist et al. (2006).

${ }^{6}$ We chose 2001 as the break point in the sample simply because the allegations made in the global settlement related to actions before this period.
} 
Finally, this study provides additional insights into the information content of analyst reports. In particular, it lends support to Brav and Lehavy (2003) and Asquith et al. (2005), who show that target prices contain information not contained in recommendations.

The remainder of the paper is organized as follows. We review the relevant literature in "Literature Review", following which we outline our econometric methodology in "Econometric Model." "Sample and Data" describes our sample and data sources and our results are presented in "Results." We provide our conclusions in "Conclusion."

\section{Literature Review}

Analysts are by no means the only factor driving a firm's choice of underwriter. Early studies of underwriter choice focused on the role that reputation plays in underwriter choice. In the presence of asymmetric information, the reputation of the underwriter plays a critical role in certifying the quality of the issuance. ${ }^{7}$ More recently, Fernando et al. (2005) argue that underwriter choice is in fact the result of two-sided matching with both underwriters and firms considering the quality of the other when choosing an underwriter.

The role of past underwriting relationships in current underwriter choice has also been examined. ${ }^{8}$ In order to certify the quality of the issuer, an underwriter acquires firm specific capital. If this information is durable, then the incumbent underwriter is an obvious choice to underwrite the current issue. $^{9}$

Several studies have focused on the role that banking relationships play in underwriter choice. As argued by Puri (1999), firm specific knowledge developed through monitoring past loans can make banks better certifiers than investment banks with no loan relationship. Yasuda (2005) shows that this is particularly the case where asymmetric information is likely to be strong, as in the case of junk issuers. Furthermore, Drucker and Puri (2005) find that commercial banks may tie commercial loans to underwriting deal flow.

Finally, the role of analysts in selecting an underwriter has also been examined. The three papers most closely related to the current study are Ljungqvist et al. (2006), Clarke et al. (2007) and Ellis et al. (2005). Ljungqvist et al. (2006) examine whether analysts' recommendations can influence the likelihood of their investment bank winning an underwriting deal. Examining a large cross-section of

\footnotetext{
${ }^{7}$ See Booth and Smith (1986).

${ }^{8}$ See for example Ljungqvist et al. (2006).

${ }^{9}$ See James (1992) for a discussion of underwriters and firm specific capital.
} 
debt and equity issuances between 1993 and 2002, they find minimal evidence that this is the case. Once the endogenous nature of analyst recommendations and the strategic coverage decisions are accounted for, they find that more optimistic recommendations are associated with a lower probability of winning an underwriting deal. They argue that this result is due to established underwriters fighting a losing battle to keep clients as new underwriters enter the market.

In a related study, Clarke et al. (2007) use a more restrictive sample of All Star analysts that change banks to examine the issue of underwriting deal flow and analyst recommendations. They find that when an All Star analyst changes banks, she does not become more optimistic in her forecasts or recommendation levels. Consistent with Ljungqvist et al. (2006), they also find that forecast bias and aggressive recommendations do not influence the probability of a bank winning an underwriting deal.

Ellis et al. (2005) examine the decision of issuers to switch underwriters for secondary equity offerings. Treating analyst coverage as exogenous with respect to the decision to switch, they find that analysts play an important role in drawing issuers to a new underwriter. In particular, when issuers downgrade to less established underwriters, they tend to choose underwriters whose analysts are providing favorable research coverage. While the results of Ellis et al. (2005) are consistent with the results in this paper, the treatment of analyst behavior is fundamentally different. Ellis et al. (2005) treat analyst behavior as exogenous to the underwriting process, that is, the analyst recommendation is not influenced by the fact that the analyst's employer has a potentially lucrative investment banking relationship with the issuer.

\section{Econometric Model}

The main question of interest in this paper is whether analyst behavior affects a firm's choice of underwriter. It is a well known fact that the behavior of underwriter-affiliated analysts differs from that of unaffiliated analysts. Michaely and Womack (1999) show that analysts affiliated with initial public

offerings are more optimistic than unaffiliated analysts. Lin and McNichols (1998) show this result holds for seasoned equity offerings, while Bradshaw et al. (2003) document that, on average, all analysts become more optimistic in terms of target prices before security issuances. The question still remains, does this behavior influence underwriter choice?

To examine the relationship between analyst behavior and underwriter choice, we appeal to the economic arguments and econometric methodology of Ljungqvist et al. (2006). At a glance, the obvious way to estimate the relationship between underwriter choice and analyst behavior is to estimate a probit model of underwriter choice on analyst behavior and variables controlling for the past 
relationship between the underwriter and the issuing firm. The key econometric insight of Ljungqvist et al. (2006) is to note that estimation of such a model is complicated by two factors. First, the decision by the investment bank to provide research coverage is unlikely to be random. That is, research coverage is systematically related to the characteristics of the firm being covered. ${ }^{10}$ Heckman (1979) shows that non-random censoring such as this leads to inconsistent estimation.

Second, even after taking account of the fact that the decision to provide research coverage is not random, an analyst's behavior is unlikely to be exogenous. Hong and Kubik (2003) and Das et al. (2006) argue that when issuing research reports, analysts are aware of the potential effect that negative reports could have on their career progression. These career concerns are likely to be quite acute when lucrative underwriting deals are at stake. Failing to account for the endogeneity of analyst behavior would once again lead to inconsistent estimation.

Ljungqvist et al. (2006) show that adjusting the probit model of underwriter choice for the systematic coverage decision and the endogenous nature of analyst behavior gives a simultaneous equations system with endogenous switching: ${ }^{11}$

Coverage:

$$
\left.\begin{array}{rl}
\text { Analyst } & =\beta_{A} X_{A}+\varepsilon_{A} \\
\text { Deal }^{*} & =\beta_{D} X_{D}+\delta_{D} \text { Analyst }+\varepsilon_{D}
\end{array}\right\} \text { if } \text { Covered }^{*}>0
$$

No Coverage:

$$
\left.\begin{array}{rl}
\text { Analyst } & =0 \\
\text { Deal }^{*} & =\beta_{D N C} X_{D N C}+\varepsilon_{D N C}
\end{array}\right\} \text { if Covered } * 0,
$$

where

$$
\begin{aligned}
& \text { Covered }=1 \text { if } \text { Covered }^{*}=\beta_{C} X_{C}+\varepsilon_{C}>0 \\
& \text { Covered }=0 \text { if Covered } * 0
\end{aligned}
$$

This model is most easily understood by breaking it into its three main components: 1) the Underwriter Choice equation; 2) the Analyst Behavior equation; and 3) the Brokerage Coverage equation. We will discuss each in turn below.

\section{Underwriter Choice Equation}

The Underwriter Choice equation models the probability of underwriting an issuance as a function of analyst behavior and controls relating to the relation of the issuing firm and the underwriter.

\footnotetext{
${ }^{10}$ See O'Brien and Bhushan (1990) for a discussion of a brokerage's decision to cover a firm.

${ }^{11}$ See Maddala (1983) for a discussion of this econometric specification.
} 
When coverage occurs, and thus we observe analyst behavior, the Underwriter Choice equation is the bottom equation in (1):

$$
\text { Deal }^{*}=\beta_{D} X_{D}+\delta_{D} \text { Analyst }+\varepsilon_{D},
$$

is the latent probability of underwriting the issue observed as a binary variable taking the value one if the bank wins the deal and zero otherwise. $X_{D}$ is a matrix of control variables measuring the past relationship between the underwriter and the issuing firm and Analyst is the measure of analyst behavior.

When an investment bank does not provide analyst coverage, and thus we do not observe any analyst behavior, the Underwriter Choice equation is the bottom equation in (2)

$$
\text { Deal }^{*}=\beta_{D N C} X_{D N C}+\varepsilon_{D N C} .
$$

The difference between (4) and (5), is that (5) does not contain any measure of analyst behavior.

\section{Analyst Behavior Equation}

An instrumental variables approach is used to control for the endogeneity in analyst behavior. Analyst behavior is modeled as a function of the costs of and benefits to the analyst for providing favorable coverage. When an investment bank provides coverage, the Analyst Behavior equation is given by the top equation in (1)

$$
\text { Analyst }=\beta_{A} X_{A}+\varepsilon_{A} \text {. }
$$

This equation models analyst behavior, Analyst, as a function of XA, the costs of and benefits to the analyst for providing favorable coverage. When coverage is not provided, we do not observe analyst behavior and the Analyst Behavior equation is the top equation in (2).

The Analyst Behavior equation and the Underwriter Choice equation form two simultaneous equations systems given by (1) and (2). Which of these two systems we observe is governed by an endogenous switching equation that directly models the bank's choice to provide analyst coverage. This switching is controlled by the Brokerage Coverage equation.

\section{Brokerage Coverage Equation}

The strategic choice of an investment bank to provide coverage is modeled by the Brokerage Coverage equation

$$
\text { Covered }^{*}=\beta_{C} Z_{C}+\varepsilon_{C} \text {. }
$$




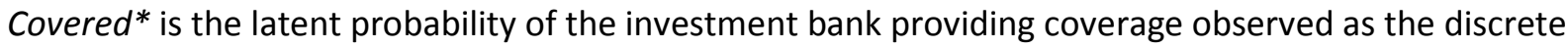
variable Covered, which takes the value one if coverage is provided and zero otherwise. $Z_{c}$ is a matrix of variables measuring the benefits to the bank from providing coverage. When coverage occurs we observe the system (1) and when coverage does not occur we observe (2).

\section{Estimation and Identification Strategy}

To estimate Eqs. 1 through 2 the following two-step estimation strategy is employed. When coverage occurs, the Analyst Behavior equation is estimated using a maximum likelihood estimation procedure based on Heckman (1979). Using the Heckman procedure accounts for the strategic coverage decision (3) and allows for consistent estimation of the Analyst Behavior equation. Analyst behavior is then instrumented in the Underwriter Choice equation using the fitted values from the Analyst Behavior equation. Consistent estimation of the Underwriter Choice equation is then possible using the Heckmanadjusted probit model of Van De Ven and Van Pragg (1981). Instrumenting for analyst behavior accounts for the endogeneity in analyst behavior, while the Heckman probit accounts for the strategic coverage decision. Following Murphy and Topel (1985), the standard errors in the Underwriter Choice equation are corrected to account for the bias introduced by the two-step estimation procedure. ${ }^{12}$

When coverage does not occur and analyst behavior is unobserved, the Underwriter Choice Eq. 2 is estimated. Once again this is done using the Heckman-adjusted probit model of Van De Ven and Van Pragg (1981).

\section{Sample and Data}

Issuing Firms, Deals, and Competing Underwriters

The underwriting deals for the analysis consist of all public and private debt and seasoned equity transactions made by firms in the 6798 SIC code from 1996 to $2004 .{ }^{13}$ Mortgage REITs and hybrid REITs were excluded from the sample leaving 161 equity REITs making issues. ${ }^{14}$ Deal specific underwriting information was obtained from Thomson Financial's SDC Platinum New Issues database.

\footnotetext{
${ }^{12}$ The maximum likelihood standard errors obtained from the Heckman probit do not account for the fact that the fitted value from the first step is measured with error. This leads to downward biased standard errors. Murphy and Topel (1985) provide an asymptotic adjustment to correct the second stage standard errors for the measurement error contained in the fitted value.

${ }^{13}$ See Boudry et al. (2010) for a discussion of REIT security issuance decisions.

${ }^{14}$ Issuances made by the limited partnership associated with a given REIT are treated as if the issuance was made by the REIT itself.
} 
For each deal, the bank or banks winning the underwriting deal are those defined by SDC as the lead underwriter on the deal. In the vast majority of cases, a single bank is the lead underwriter, but in the sample as many as three banks are labeled as lead underwriter for a given deal. ${ }^{15}$

Table 1 reports descriptive statistics of the deals in the estimation sample. For both debt and seasoned equity deals, there is considerable time series variation in the number and size of deals coming to market. Equity deals tend to be smaller than debt deals, with the average seasoned equity issuance being $\$ 90$ million and the average debt issuance being $\$ 100$ million. These average numbers are slightly smaller than the averages reported by Ljungqvist et al. (2006) for a broader cross-section of firms. There is also a noticeable decline in underwriting activity in 1999 and 2000, which coincides with the weak real estate market of the late 1990s. In total, the sample of issuing firms raised $\$ 76,405$ million in debt and \$72,156 million in seasoned equity from 1996 to 2004.

\section{Underwriting Competition}

Underwriting market concentration for REITs has changed dramatically through time. This suggests that competition is also likely to have changed during this time period. ${ }^{16}$ Table 2 and Table 3 report equity and debt underwriting market share for the major banks in the sample. Most noticeably, Merrill Lynch dominated the underwriting market in the first half of the sample. In fact, before the emergence of commercial banks as significant underwriters in 2001, the number of underwriters that were actively underwriting deals was quite limited. ${ }^{17}$ Interestingly, in the latter part of the sample, no individual bank dominates the underwriting market.

In testing the role that analysts play in underwriter choice, it is necessary to make some judgment about exactly which underwriters were competing for a given deal. The approach taken in Ljungqvist et al. (2006) to designate whether a bank was competing for a deal is twofold. First, the final underwriting entities that survived the market consolidation are assumed to be competing for every deal. Second, the underwriters that merged into the surviving underwriters are assumed to be competing for every deal before their eventual merger. This leads to potentially over 25 banks competing for a given deal.

\footnotetext{
${ }^{15}$ See Corwin and Schultz (2005) and Ljungqvist et al. (2009) for a discussion of underwriting syndication.

${ }^{16}$ The normalized Hirschman-Herfindahl Index falls from over 0.2 to around 0.1 during the sample period. In terms of competition, the Department of Justice considers a $\mathrm{HHI}$ of 0.1 to 0.18 to be moderately concentrated. See their web page for a discussion http://www.usdoj.gov/atr/public/testimony/hhi.htm.

${ }^{17}$ See Gande et al. (1999) for a discussion of the entrance of commercial banks into the bond underwriting market after the relaxation of Section 20 of the Glass-Steagall Act.
} 
Table 1 Deal characteristics

\begin{tabular}{|c|c|c|c|c|c|}
\hline \multicolumn{6}{|c|}{ Panel A: Equity Deals } \\
\hline Year & Obs & Mean & Std Dev & Min & $\operatorname{Max}$ \\
\hline 1996 & 86 & 93.9 & 83.7 & 8 & 406 \\
\hline 1997 & 163 & 102.6 & 94.1 & 4 & 518 \\
\hline 1998 & 188 & 61.6 & 78.3 & 2 & 562 \\
\hline 1999 & 31 & 86.6 & 64.1 & 10 & 298 \\
\hline 2000 & 7 & 116.2 & 192.8 & 28 & 552 \\
\hline 2001 & 56 & 114.1 & 114.3 & 11 & 584 \\
\hline 2002 & 52 & 103 & 97.2 & 3 & 397 \\
\hline 2003 & 103 & 89 & 50.2 & 5 & 254 \\
\hline 2004 & 111 & 102.4 & 72.9 & 14 & 488 \\
\hline \multicolumn{6}{|c|}{ Panel B: Debt Deals } \\
\hline Year & Obs & Mean & Std Dev & Min & $\operatorname{Max}$ \\
\hline 1996 & 92 & 43.3 & 40.4 & 3 & 250 \\
\hline 1997 & 170 & 49.3 & 54.2 & 2 & 250 \\
\hline 1998 & 124 & 84.6 & 87.3 & 2 & 400 \\
\hline 1999 & 74 & 101 & 105.7 & 2 & 500 \\
\hline 2000 & 67 & 96 & 126.5 & 5 & 600 \\
\hline 2001 & 47 & 195.5 & 215.1 & 10 & 1100 \\
\hline 2002 & 63 & 164.2 & 181.1 & 2 & 800 \\
\hline 2003 & 59 & 133.1 & 109.3 & 6 & 500 \\
\hline 2004 & 73 & 168 & 165.1 & 25 & 1000 \\
\hline
\end{tabular}

Table reports descriptive statistics for issuances by 161 equity REITs from 1996 to 2004. Panel A reports both public and private seasoned equity issuances. Panel B reports public and private debt issuances. All values are in millions

The approach we adopt in this paper is different. We make two assumptions. First, if a bank is competing for the average deal that comes to market, one would expect to observe ex post, that the bank won some market share each year. It is highly unlikely that a bank would compete on every deal and lose every deal. Second, if a bank is competing for the average deal that comes to market, then the deals it wins should appear on average, like the average deal that comes to market.

Examining the market share of the underwriters in our sample will illustrate our "competing bank" rule. Table 2 and Table 3 report the equity and debt market share. It is apparent that there is a core group of underwriters that consistently obtain a credible market share each year. Notice however, that this group is not constant across debt and equity markets and also changes through time. Using the first part of our competing bank rule above, we define the competing banks in Table 4. Panel $A$ lists banks competing for equity deals, while Panel B lists banks competing for debt deals. These entities include all subsidiaries associated with the underwriter at the time of the deal. ${ }^{18}$

\footnotetext{
${ }^{18}$ For example, in 2002 a deal underwritten by Citigroup is considered to be underwritten by Salomon Smith Barney.
} 
Table 2 Equity underwriting market share

\begin{tabular}{lccccccccccc}
\hline Underwriter & 1995 & 1996 & 1997 & 1998 & 1999 & 2000 & 2001 & 2002 & 2003 & 2004 \\
\hline Banc of America Securities & 0 & 0 & 0.12 & 0.73 & 0 & 0 & 1.17 & 2.23 & 1.85 & 1.29 \\
$\quad$ LLC & & & & & & & & & & \\
Bear Steams \& Co. Inc & 0 & 0.53 & 2.59 & 1.92 & 1.72 & 0 & 0 & 5.07 & 4.41 & 5.7 \\
Credit Suisse First Boston & 0 & 0 & 0 & 0.31 & 0 & 8.35 & 2.12 & 2.43 & 6.74 & 2.2 \\
Deutsche Bank Securities & 0 & 0 & 0.72 & 0 & 0.37 & 0 & 0.48 & 17.02 & 5.2 & 3.97 \\
Donaldson, Lufkin \& Jenrette & 5.16 & 7.29 & 9.02 & 2.74 & 3.71 & 4.92 & 0 & 0 & 0 & 0 \\
Goldman Sachs \& Co. & 9.8 & 5.04 & 12.1 & 8.14 & 6.27 & 38.62 & 17.56 & 6.13 & 6.13 & 8.72 \\
JP Morgan Chase & 0 & 0.43 & 0.58 & 1.26 & 0 & 0 & 0 & 0 & 0 & 2.7 \\
Lehman Brothers & 3.64 & 15.34 & 10.79 & 5.84 & 11.04 & 4.78 & 9.34 & 0.04 & 2.4 & 5.15 \\
Merrill Lynch \& Co. Inc. & 44.78 & 41.83 & 27.36 & 33.72 & 29.2 & 14.32 & 20.51 & 16.24 & 13.37 & 7.36 \\
MSDW & 3.81 & 0 & 7.32 & 7.04 & 11.29 & 33.93 & 6.73 & 11 & 7.05 & 11.53 \\
Paine Webber & 8.4 & 1.61 & 3.11 & 3.69 & 1.3 & 0 & 0 & 0 & 0 & 0 \\
Prudential & 1.35 & 6.09 & 9.13 & 6.83 & 1.02 & 0 & 0.43 & 0 & 0 & 0 \\
Salomon Smith Barney & 11.2 & 10.91 & 10.24 & 9.92 & 26.41 & 0 & 30.22 & 21.78 & 15.71 & 24.2 \\
UBS & 0 & 0 & 0 & 0 & 0 & 0 & 6.07 & 8.48 & 3.52 & 5.62 \\
Wachovia Securities & 0 & 0 & 0 & 0 & 0 & 0 & 0.95 & 2.41 & 16.32 & 11.12 \\
Total & 88.15 & 89.06 & 93.08 & 82.13 & 92.33 & 104.92 & 95.57 & 92.82 & 82.7 & 89.56 \\
\hline
\end{tabular}

Table reports annual equity underwriting market share for selected underwriters from 1995 to 2004. Equity issuances include all public and private equity transactions made by 161 equity REITs as reported by the SDC Platinum New Issues database. Market share may sum to greater than $100 \%$ during years of underwriter mergers, because underwriting deals during that year, but pre-merger, will be assigned to both the underwriting bank and the merged entity. All values are percentages

The market share of the competing banks does not account for all the underwriting activity in the sample. Smaller underwriters, such as Keybank or BB\&T Capital, which underwrite deals infrequently, are considered to be competing only for the deals that they win. For both debt and equity deals, the deals that these smaller underwriters win, are on average, less than half the size of the deals won by the larger banks. For equity deals the average size of a deal won by a competing bank is $\$ 110$ million compared to $\$ 50$ million for smaller banks. For debt deals the comparison is $\$ 135$ million versus $\$ 52$ million. Given the smaller average size of the deals they underwrite and the infrequency with which they underwrite deals, it is unlikely that these smaller banks actively compete for the average deal that comes to market.

It is important to note that we are applying our selection rule at the industry level for two reasons. First, we believe that this is the appropriate level at which competition should be gauged. As is evident from our sample, while at the aggregate level it may appear that a bank is a competing underwriter, at the industry level this may not be the case. Second, when we use the selection rule of Ljungqvist et al. (2006) our results are far weaker. From an econometric standpoint their selection rule 
introduces noise into the system by assuming underwriters are competing for deals when they more than likely are not. ${ }^{19}$

Table 3 Debt underwriting market share

\begin{tabular}{|c|c|c|c|c|c|c|c|c|c|c|}
\hline Underwriter & 1995 & 1996 & 1997 & 1998 & 1999 & 2000 & 2001 & 2002 & 2003 & 2004 \\
\hline $\begin{array}{l}\text { Banc of America Securities } \\
\text { LLC }\end{array}$ & 0 & 4.71 & 0 & 0.15 & 1 & 3.76 & 20.53 & 17.31 & 20.55 & 13.94 \\
\hline Bear Steams \& Co. Inc & 0 & 0 & 0 & 0 & 0 & 0.54 & 0 & 0 & 0 & 2.51 \\
\hline Credit Suisse First Boston & 0 & 0 & 0 & 0 & 0 & 1.87 & 5.64 & 5.17 & 5.99 & 3.76 \\
\hline Deutsche Bank Securities & 0 & 0 & 0 & 0 & 1.34 & 6.5 & 10.07 & 2.02 & 5.55 & 6.96 \\
\hline Donaldson, Lufkin \& Jenrette & 0 & 0.59 & 1.62 & 1.91 & 0.27 & 1.63 & 0 & 0 & 0 & 0 \\
\hline Goldman Sachs \& Co. & 16.21 & 20.89 & 24.54 & 13.61 & 16.35 & 6.22 & 2.25 & 6.77 & 6.67 & 5.5 \\
\hline JP Morgan Chase & 11.04 & 26.32 & 18.68 & 20.03 & 13.69 & 6.51 & 17.87 & 17.14 & 11.05 & 23.41 \\
\hline Lehman Brothers & 7.7 & 9.96 & 7.66 & 3.89 & 6.3 & 24.58 & 10.83 & 21.36 & 5.62 & 0 \\
\hline Merrill Lynch \& Co. Inc. & 27.02 & 27.57 & 33.66 & 37.17 & 40.66 & 16.33 & 6.18 & 11.17 & 4.32 & 4.84 \\
\hline MSDW & 0 & 4.89 & 16.3 & 0.48 & 17.63 & 0.37 & 0 & 7.41 & 2.62 & \\
\hline Paine Webber & 0 & 0 & 2.03 & 3.34 & 1.67 & 0 & 0 & 0 & 0 & 0 \\
\hline Prudential & 0 & 0 & 0 & 0.24 & 0 & 0 & 0 & 0 & 0 & 0 \\
\hline Salomon Smith Barney & 6.53 & 0 & 1.16 & 0.71 & 8.68 & 4.67 & 20.86 & 7.99 & 10.24 & 13.87 \\
\hline UBS & 0.23 & 0 & 0.8 & 1.22 & 0.47 & 4.67 & 4.24 & 3.49 & 9.47 & 9.3 \\
\hline Wachovia Securities & 0 & 0 & 0 & 0 & 0 & 0 & 1.07 & 6.52 & 9.68 & 11.98 \\
\hline Total & 82.24 & 90.03 & 95.04 & 98.57 & 90.9 & 94.9 & 99.9 & 98.93 & 96.54 & 98.69 \\
\hline
\end{tabular}

Table reports annual debt underwriting market share for selected underwriters from 1995 to 2004. Debt issuances include all public and private debt transactions made by 161 equity REITs as reported by the SDC Platinum New Issues database. Market share may sum to greater than $100 \%$ during years of underwriter mergers, because underwriting deals during that year, but pre-merger, will be assigned to both the underwriting bank and the merged entity. All values are percentages

\section{Brokerages and Coverage}

The primary source of analyst data for the study is the First Call Historical Database. First Call provides stock recommendations, earnings estimates and actuals, and target stock prices taken from analyst reports, morning minutes, and phone calls with analysts. Using First Call does, however, have a few limitations. First, First Call reports all statistics at the brokerage level, so in contrast to l/B/E/S, it is impossible to identify the actual analyst making the report. ${ }^{20}$

Second, First Call sometimes back fills the brokerage identifier when mergers occur among brokerages. For example, analyst reports for Deutsche Bank Alex Brown go back to 1996 in First Call,

\footnotetext{
${ }^{19}$ A classic example is Thomas Weisel Partners, which competes for all deals in the Ljungqvist et al. (2006) study, but has never underwritten a REIT offering and is unlikely ever to, since it focuses on growth industries.

${ }^{20}$ A comparison of First Call's brokerage level target prices and hand collected reports from Investext, in which the analyst is identifiable, suggests that First Call's estimates come from lead analysts.
} 
even though the entity only came into existence in $1999 .{ }^{21}$ This backfilling effectively masks the identity of the brokerage issuing target prices before the brokerage merger took place. While this would prove problematic for a larger sample of firms, the unique brokerage composition of the REIT market mitigates this problem. The reason for this is that where back filling occurred, REIT analysts were only on one side of the merger. Consequently, it is possible to track brokerages even though they have been back filled. This does, however, present a problem in expanding the sample out of the REIT universe. ${ }^{22}$

Finally, First Call does have holes in its coverage records. To fill these gaps, we hand collect analyst reports from Investext. Investext provides access to analyst reports issued by many investment banks. Where required, we collect recommendation and target price data for banks competing on an underwriting deal. These data are combined with the First Call data to generate the final sample of analyst data. ${ }^{23}$

An investment bank is considered to be covering a firm at the time of a security issuance if a brokerage affiliated with that bank provides analyst reports in the 365-day window prior to the deal. A brokerage is affiliated with an investment bank while it is a subsidiary of the investment bank. For example, after their merger, although Citigroup does not provide analyst coverage, Salomon Smith Barney does, so for deals involving Citigroup, Citigroup is treated as providing coverage if Salomon Smith Barney analysts issue reports in the 365 days prior to the deal.

Table 5 reports descriptive statistics on the number of competing analysts covering issuing firms through time. In the early part of the sample, there were typically only one or two affiliated analysts providing research coverage on issuing firms. This number grows during the sample, to have, on average, three competing analysts covering equity deals and four to five covering debt deals.

For some deals, however, nearly all competing banks provide analyst coverage. Although small in absolute magnitude, the level of coverage is consistent with the mid-cap nature of REITs.

\footnotetext{
${ }^{21}$ There does not appear to be a systematic rule governing back filling. For example, while Deutsche Bank is back filled, the Paine Webber and UBS merger is not.

${ }^{22}$ Essentially what it entails is checking for each industry whether both merged banks provided analyst coverage, and if so, dropping all observations before the merger. Dropping observations in this nonrandom manner has the potential to lead to some unwelcome sample selection issues.

${ }^{23}$ Although both Investext and First Call are incomplete in their individual coverage, the merged data set for the brokerages of concern in this study, is similar to the coverage provided by $\mathrm{l} / \mathrm{B} / \mathrm{E} / \mathrm{S}$.
} 


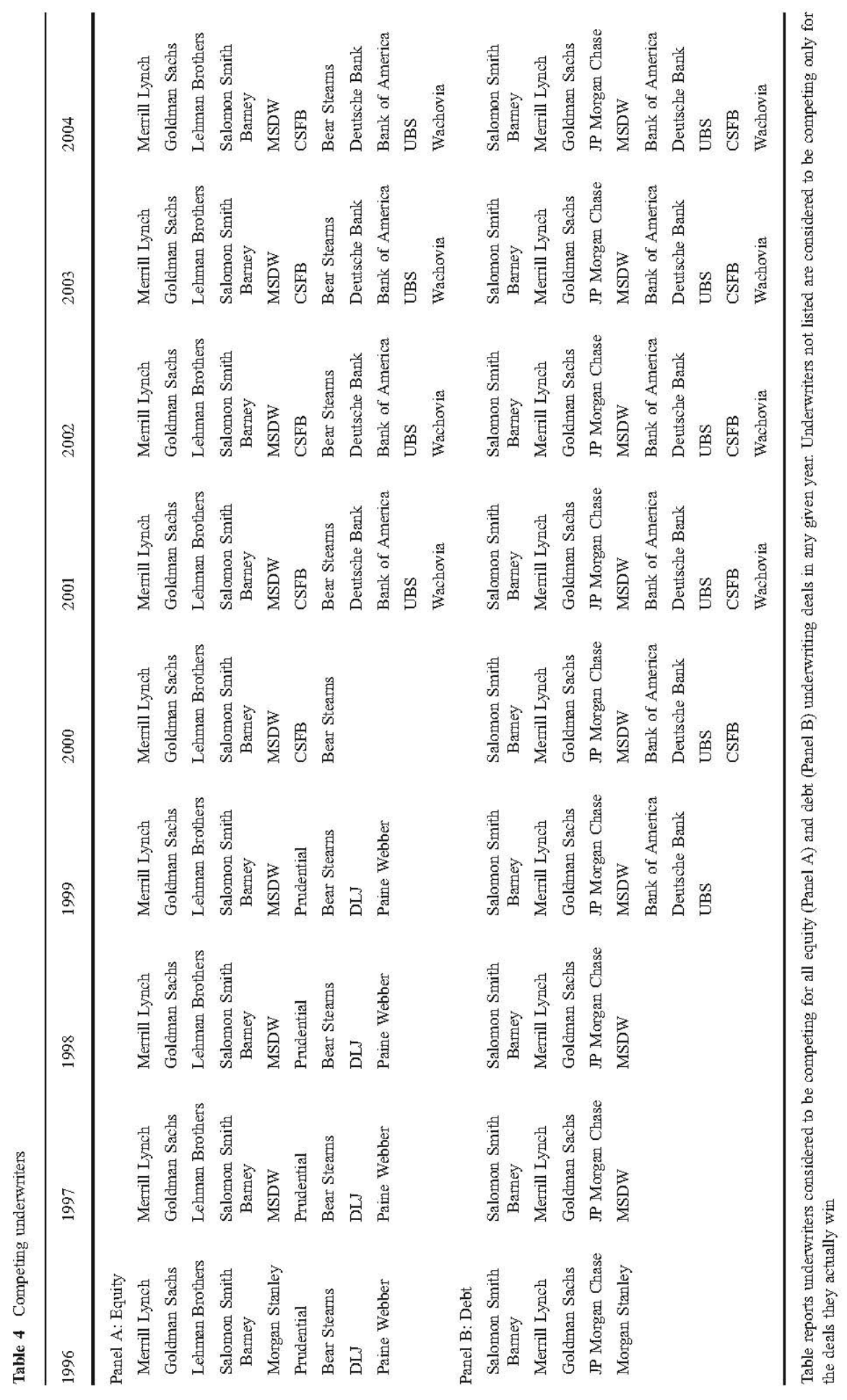

Measures of Analyst Behavior

What constitutes favorable analyst coverage is open to interpretation. The metrics we use to capture favorable analyst coverage are based on two assumptions. First, all else equal, a firm prefers an 
analyst to be optimistic. Issuing a Sell recommendation or a target stock price below the current stock price is not favorable from the perspective of the firm. Second, among a group of analysts, the firm considers the one issuing the most optimistic research to be the most favorable. A firm considers an analyst issuing a Sell recommendation to be more favorable than one issuing a Strong Sell, even though neither is optimistic. In a similar manner, a firm considers an analyst with a higher target stock price to be more favorable than another, even if both are below the current stock price.

Table 5 Analyst coverage and competition

\begin{tabular}{|c|c|c|c|c|c|c|c|c|c|c|}
\hline \multirow[b]{2}{*}{ Year } & \multicolumn{5}{|c|}{ Analyst Coverage } & \multicolumn{5}{|c|}{ Competitors } \\
\hline & Obs & Mean & Std Dev & Min & $\operatorname{Max}$ & Obs & Mean & Std Dev & Min & $\operatorname{Max}$ \\
\hline \multicolumn{11}{|c|}{ Panel A: Equity Deals } \\
\hline 1996 & 86 & 1.85 & 1.34 & 0 & 5 & 86 & 10.24 & 0.43 & 10 & 11 \\
\hline 1997 & 163 & 2.32 & 1.61 & 0 & 6 & 163 & 9.17 & 0.37 & 9 & 10 \\
\hline 1998 & 188 & 3.16 & 1.73 & 0 & 7 & 188 & 11.26 & 0.44 & 11 & 12 \\
\hline 1999 & 31 & 2.68 & 1.54 & 0 & 6 & 31 & 11.13 & 0.34 & 11 & 12 \\
\hline 2000 & 7 & 2.86 & 1.21 & 1 & 4 & 7 & 8.14 & 0.38 & 8 & 9 \\
\hline 2001 & 56 & 3.18 & 2.05 & 0 & 9 & 56 & 10.16 & 0.37 & 10 & 11 \\
\hline 2002 & 52 & 2.17 & 1.7 & 0 & 8 & 52 & 11.21 & 0.41 & 11 & 12 \\
\hline 2003 & 103 & 3.65 & 2.46 & 0 & 10 & 103 & 11.23 & 0.53 & 11 & 13 \\
\hline 2004 & 111 & 2.84 & 1.84 & 0 & 7 & 111 & 11.22 & 0.46 & 11 & 13 \\
\hline \multicolumn{11}{|c|}{ Panel B: Debt Deals } \\
\hline 1996 & 92 & 1.55 & 0.99 & 0 & 3 & 92 & 4.16 & 0.37 & 4 & 5 \\
\hline 1997 & 170 & 1.98 & 1.11 & 0 & 5 & 170 & 5.22 & 0.41 & 5 & 6 \\
\hline 1998 & 124 & 2.89 & 1.32 & 0 & 6 & 124 & 6.15 & 0.38 & 6 & 8 \\
\hline 1999 & 74 & 2.65 & 1.51 & 0 & 6 & 74 & 7.35 & 0.51 & 7 & 9 \\
\hline 2000 & 67 & 3.37 & 1.86 & 0 & 10 & 67 & 9.33 & 0.47 & 9 & 10 \\
\hline 2001 & 47 & 6.06 & 2.44 & 1 & 11 & 47 & 10.26 & 0.44 & 10 & 11 \\
\hline 2002 & 63 & 4.46 & 1.93 & 0 & 8 & 63 & 10.14 & 0.35 & 10 & 11 \\
\hline 2003 & 59 & 5.25 & 2.27 & 1 & 9 & 59 & 10.27 & 0.45 & 10 & 11 \\
\hline 2004 & 73 & 3.79 & 2.02 & 0 & 9 & 73 & 10.52 & 0.58 & 10 & 12 \\
\hline
\end{tabular}

Table reports descriptive statistics for analyst coverage by year. Panel A reports results for equity deals, while Panel B reports results for debt deals. Analyst data are from First Call Historical database and hand collected analyst reports from Investext

Following these two assumptions, we develop two measures of relative analyst optimism, the first based on target stock prices and the second on recommendations. The relative analyst price is

$$
R A P=\left(\frac{T P}{P}\right)+\left(\frac{T P-\max (T P)}{T P}\right)\left(\frac{P}{P_{T P}}\right)
$$

where TP is the analyst's target price, $\mathrm{P}$ is the share price the day before the analyst's estimate was made, $\max (T P)$ is the maximum target price made by competing analysts and $\mathrm{P}_{\mathrm{TP}}$ is the price the day before the $\max (T P)$ estimate was made. 
The first part of (8) measures the analyst's general optimism or pessimism. If the target price is above the current price this number is greater than one. The second part of (8) adjusts the analyst's target price relative to the most optimistic target price issued by their competitors. If the analyst does not have the most optimistic target price, $\left(\frac{T P-\max T P}{T P}\right)$ will be negative. This is multiplied by $\left(\frac{P}{P_{T P}}\right)$ to adjust for the fact that analysts do not make reports at exactly the same time, so the current share price will, in general, be different when the analyst under consideration and the most optimistic analyst issue their target prices.

The relative analyst recommendation is

$$
R A R=(\operatorname{Rec}-\text { Hold })+\frac{(\operatorname{Rec}-\max (\operatorname{Rec}))}{\operatorname{Rec} .}
$$

where, $\operatorname{Rec}$ is the analyst's recommendation, $\max (\operatorname{Rec})$ is the maximum recommendation observed among competing analysts and Hold is a hold or neutral recommendation (coded as 3 in our data.) The first part of (9) captures whether the analyst is optimistic or pessimistic. Buy or Strong Buy recommendations (coded 4 and 5) will produce a positive number, while Sell or Strong Sell (coded 2 and 1) will produce a negative number. The second part of (9) adjusts for the fact that, although being optimistic, the analyst may not be the most optimistic analyst among competitors for the deal. Whenever the analyst is less optimistic than the most optimistic analyst, this adjustment will be negative.

The relative analyst recommendation measure differs from the metric used in the prior literature to measure analyst behavior. Ljungqvist et al. (2006) use the deviation of the analyst's recommendation from that of the median recommendation that analysts report. A potential weakness of this measure is that it fails to capture whether the analyst is, in general, optimistic or pessimistic. Using their metric, all analysts recommending a stock with a buy recommendation yields the same result as all analysts recommending selling the stock. That is, in both cases the recommendation minus the median recommendation is zero, when a firm clearly has a preference for all brokerages issuing buy recommendations. ${ }^{24}$

Recommendations and target prices are not the only information that analysts report. Analyst earnings forecasts are readily available and have been extensively studied in the accounting literature. The problem with employing them to measure favorable analyst coverage, is that it is not obvious what a firm would consider to be favorable in terms of an analyst's earnings estimate. Bartov et al. (2002)

\footnotetext{
${ }^{24}$ Ljungqvist et al. (2006) also try several other metrics, but each is a variant of a recommendation minus the median recommendation.
} 
show that the market reacts positively to firms that beat earnings estimates. Given that this is the case, firms may actually prefer lower earnings estimates, since this gives them an easier target to beat. However, it is unlikely that the firm would want the target too low, as this would give a negative signal about the firm's prospects. Identifying this band of favorable estimates is problematic, so we do not employ any measure based on earnings forecasts.

Table 6 reports descriptive statistics for both analyst behavior measures for both debt and equity deals. Two trends are noticeable from Table 6. First, consistent with Ljungqvist et al. (2006), analysts from winning banks are, on average, relatively more optimistic than analysts from losing banks. That is, the mean relative analyst price and relative analyst recommendations for winning banks are significantly larger than the mean for losing banks. This result is true for both debt and equity deals and for both the pre and post 2001 periods. Second, there is a marked decline in the level of optimism post 2001 for both winning and losing banks. This period coincides with SEC investigations into analyst/underwriter conflicts, which may be responsible for the overall decline in optimism in this part of the sample.

Table 6 Measures of analyst behavior

\begin{tabular}{|c|c|c|c|c|c|c|c|c|c|c|c|}
\hline & \multicolumn{5}{|c|}{ Winning Banks } & \multicolumn{6}{|c|}{ Losing Banks } \\
\hline & Obs & Mean & $\begin{array}{l}\text { Std } \\
\text { Dev }\end{array}$ & Min & $\operatorname{Max}$ & Obs & Mean & $\begin{array}{l}\text { Std } \\
\text { Dev }\end{array}$ & Min & $\operatorname{Max}$ & $\mathrm{t}$ \\
\hline \multicolumn{12}{|c|}{ Panel A: Pre 2001 Equity Deals } \\
\hline $\begin{array}{l}\text { Relative Analyst } \\
\text { Recommendation }\end{array}$ & 252 & 1.228 & 0.685 & -0.667 & 2 & 966 & 1.019 & 0.886 & -0.667 & 2 & 3.47 \\
\hline $\begin{array}{l}\text { Relative Analyst } \\
\text { Price }\end{array}$ & 202 & 1.129 & 0.092 & 0.5 & 1.293 & 761 & 1.092 & 0.099 & 0.452 & 1.297 & 4.73 \\
\hline \multicolumn{12}{|c|}{ Panel B: Post 2001 Equity Deals } \\
\hline $\begin{array}{l}\text { Relative Analyst } \\
\text { Recommendation }\end{array}$ & 221 & 0.36 & 1.26 & -5 & 2 & 860 & -0.047 & 1.366 & -6 & 2 & 4.02 \\
\hline $\begin{array}{l}\text { Relative Analyst } \\
\text { Price }\end{array}$ & 252 & 1.012 & 0.153 & 0.385 & 1.28 & 877 & 0.943 & 0.202 & -0.082 & 1.29 & 5.01 \\
\hline \multicolumn{12}{|c|}{ Panel C: Pre 2001 Debt Deals } \\
\hline $\begin{array}{l}\text { Relative Analyst } \\
\text { Recommendation }\end{array}$ & 292 & 1.095 & 0.829 & -1.5 & 2 & 1191 & 0.833 & 0.926 & -2.5 & 2 & 4.43 \\
\hline $\begin{array}{l}\text { Relative Analyst } \\
\text { Price }\end{array}$ & 232 & 1.117 & 0.095 & 0.759 & 1.296 & 963 & 1.091 & 0.124 & 0.13 & 1.3 & 2.98 \\
\hline \multicolumn{12}{|c|}{ Panel D: Post 2001 Debt Deals } \\
\hline $\begin{array}{l}\text { Relative Analyst } \\
\text { Recommendation }\end{array}$ & 207 & 0.379 & 1.193 & -5 & 2 & 1099 & 0.057 & 1.207 & -6 & 2 & 3.52 \\
\hline $\begin{array}{l}\text { Relative Analyst } \\
\text { Price }\end{array}$ & 217 & 0.987 & 0.161 & 0.386 & 1.286 & 1158 & 0.962 & 0.155 & 0.198 & 1.283 & 2.2 \\
\hline
\end{tabular}

Table reports descriptive statistics for the relative analyst price (8) and relative analyst recommendation (9). Panel A reports results for equity deals pre 2001, while Panel B reports results for equity deals post 2001. Panels C and D report results for debt deals pre and post 2001 respectively. $t$ tests are for difference in means between winning banks and losing banks 
The Costs and Benefits Facing Analysts $X_{A}$

Analysts face competing forces when issuing research. These forces range from actual payments made by investment banks to provide favorable coverage, ${ }^{25}$ to negative career outcomes related to producing unfavorable research. ${ }^{26}$ This suggests that analysts face potentially strong incentives to provide favorable coverage. Counteracting this incentive to issue favorable coverage is the fact that analysts that are less accurate compared to their peers face a higher probability of job turnover. ${ }^{27}$

Econometric identification of the simultaneous equations system (1) requires the usual rank condition that XA contains at least one variable not contained in XD. That is, there needs to be at least one variable that influences analyst behavior that is not ex ante related to the firm's choice of underwriter. Following Ljungqvistet al. (2006), we appeal to the career concerns arguments of Hong and Kubik (2003) and Hong et al. (2000) to satisfy this condition. A good instrument for analyst behavior is one that captures these costs and benefits, but is not ex ante related to the firm's choice of underwriter.

Direct measurement of the costs and benefits facing an analyst to produce favorable coverage is impossible. Side payments made by investment banks to analysts are not available and there is no direct measure of negative career outcomes (or the threat thereof) related to producing unfavorable research. These costs and benefits are, however, likely to be related to the observable characteristics of the deal, the underwriter, the brokerage and the issuing firm.

The characteristics of the deal, such as the proceeds from the deal are likely to be positively related to analyst optimism. Larger deals are likely to be more important to underwriters and as such are likely to be associated with more pressure to produce favorable coverage. Proceeds is the log of the proceeds from the current issue, excluding over-allotment options.

Following Ljungqvist et al. (2006), we also include Fee to Last. Fee to Last is the fee from the current deal divided by the bank's past year fee revenue. This measures how important the deal is to the bank. The larger this number the more incentive the analyst has to provide favorable coverage. ${ }^{28}$

If an underwriter has very loyal clients, then the pressure faced by analysts to issue favorable research is likely to be lower. ${ }^{29}$ Loyalty is a loyalty index measuring how often in the past five years the

\footnotetext{
${ }^{25}$ See the SEC's web page, http://www.sec.gov/spotlight/globalsettlement.htm for examples.

${ }^{26}$ See Gasparino (2005) and Cole (2001) for numerous illustrative examples.

${ }^{27}$ See Mikhail et al. (1999).

${ }^{28}$ For new entrants the last year fee revenue is zero. For these firms Fee to Last is set equal to one.

${ }^{29}$ See Burch et al. (2005) for a discussion of underwriter loyalty.
} 
underwriter retains its clients in consecutive deals divided by the total number of clients during this period. ${ }^{30}$

We also include Reputation, the underwriter's market share in the last 3 years. Underwriters who have greater market share are likely to be viewed as more reputable and may be unwilling to pressure analysts to gain business.

Ljungqvist et al. (2006) argue that analysts who have invested heavily in reputational capital are likely to find it more costly to issue optimistic coverage to help attract underwriting deal flow. Following them, we include two variables that measure analyst reputation. First, All Star is a dummy variable taking the value of one if the analyst was ranked as an All Star or runner up in the previous year by Institutional Investor. ${ }^{31}$ Using the First Call data, we are unable to identify the individual analysts issuing a report. Therefore it is possible that a junior analyst at a brokerage could issue biased research in place of an All Star and we would still assign to this analyst an All Star ranking. We do not believe this is a major concern for two reasons. First, an examination of First Call's brokerage level target price with Investext's analyst level target prices, suggests that First Call's target prices come from lead analysts. Second, since Institutional Investor recognizes both the All Star analyst and her team in its ranking, it is still likely that an All Star analyst's reputation would be damaged by a junior analyst issuing such a report and would try to prevent it from being issued.

Second, Industry Coverage is the percentage of the REIT industry covered by the brokerage. Brokerages that are real estate specialists and cover a large cross-section of the industry are likely to have invested more in reputational capital. One would expect these brokerages to find it more costly to provide overly favorable research coverage.

The characteristics of the firm are also likely to affect the costs an analyst faces when issuing favorable coverage. We include four variables related to firm characteristics. First, Volatility is the monthly return volatility for the REIT in the 12 months prior to the issuance. Firms with greater uncertainty surrounding their performance give analysts greater ability to justify their favorable research, ex post, to clients. This decreases the potential costs to an analyst of issuing overly optimistic research. Higher volatility should be associated with more optimistic coverage.

Second, Size is the log of the issuing firm's market capitalization. Since larger firms are typically associated with higher institutional ownership, one would expect a negative relationship between size

\footnotetext{
${ }^{30}$ This is a simplified version of the measure used in Burch et al. (2005) and is the same as that used by Ljungqvist et al. (2006) and Ellis et al. (2005).

${ }^{31}$ See Stickel (1992) and Fang and Yasuda (2009) for a discussion of All Star analysts.
} 
and analyst optimism. ${ }^{32}$ Since institutional investors value unbiased research and brokerages earn revenues from institutional trading, analysts face potentially higher costs issuing optimistic research for large firms. ${ }^{33}$

Third, Time to Turnover is the mean over the past twelve months, of the ratio of shares outstanding to monthly trading volume. Increased trading activity is also likely to increase the attention paid by traders to the research produced by analysts covering a given stock. This increases the potential costs the analyst faces in producing favorable research. Since a higher number for Time to Turnover implies lower trading activity, it is expected that Time to Turnover will have a positive coefficient in the analyst behavior equation.

Finally, we include Past Deals the log of the volume of past deals the firm has done in the previous 3 years. Firms that access the capital markets more frequently or raise capital in greater volumes are potentially lucrative targets for underwriters, suggesting analysts may face more pressure to win business from such firms.

\section{Underwriter-Firm Relationship Variables $X_{D}$}

The past relationship between the underwriter and the firm is likely to play an important role in the choice of underwriter. A strong prior underwriting relationship is likely to imply high firm specific information, which makes the incumbent underwriter an obvious choice to underwrite the current issue. James (1992) argues that since this firm specific information decreases with time, this relationship is more important for firms that raise capital frequently. Due to the frequency with which REITs come to market, these past relationships should be a dominant force behind underwriter choice.

Following Ljungqvist et al. (2006), we measure the relationship between the bank and the issuer using three variables. The first two are the percentage of the firm's prior 3-year equity and debt issuances that the bank has underwritten. ${ }^{34}$ This percentage share of equity and debt underwriting includes all public and private equity and debt issuances recorded in SDC's New Issues database. Furthermore, the share for any given underwriter includes the share underwritten by them or by a predecessor underwriter. For example, after the merger of Deutsche Bank and Banker's Trust Alex

\footnotetext{
${ }^{32}$ See Boudry et al. (2007) for a discussion of REIT institutional ownership.

${ }^{33}$ See Ljungqvist et al. (2007) for a discussion.

${ }^{34}$ All results are similar if a 5-year window is used.
} 
Brown in 1999, the past underwriter relationship for the merged entity Deutsche Bank Alex Brown includes all deals underwritten by Deutsche Bank and BT Alex Brown in the past three years. ${ }^{35}$

The third measure of the underwriter-issuer relationship is the percentage of the firm's syndicated loans that the bank has arranged in the past three years. As argued by Puri (1999), firm specific knowledge developed through monitoring past loans can make banks better certifiers than investment banks with no loan relationship. Yasuda (2005) shows that this is particularly the case where asymmetric information is likely to be strong, as in the case of junk issuers. Loan data come from Loan Pricing Corporation's Dealscan database. Dealscan reports loan specific information for each loan including the borrower's name, the amount and type of loan and the name of the lending syndicate. Lenders and borrowers were then matched to underwriters and REITs by name. As is the case with past underwriting relationships, the share of past loans includes the share of predecessor banks.

Underwriter reputation also plays an important role in security issuances. ${ }^{36}$ Following Megginson and Weiss (1991), underwriter reputation is proxied by the underwriter's market share of the REIT debt and equity underwriting market in the past year. Larger market shares are likely to be associated with a higher probability of winning the current issuances. ${ }^{37}$ Banks may also be able to compete for underwriting business by sweetening the terms of syndicated loans. ${ }^{38}$ Following Ljungqvist et al. (2006), this is controlled for using underwriter's share of the syndicated loan market in the previous years.

Table 7 reports descriptive statistics for the underwriter reputation and underwriter-issuer relationship variables. As expected, and consistent with the prior literature, banks that win underwriting deals have, on average, underwritten a significantly larger amount of the firm's debt and equity in the last three years. This is particularly true for underwriters not providing analyst coverage. Table 7 also shows that winning underwriters tend to have stronger past loan relationships.

\footnotetext{
${ }^{35}$ See Corwin and Schultz (2005) Appendix A for a list of investment bank mergers. The date of the remaining mergers in the sample were obtained from searches of Lexis-Nexis.

${ }^{36}$ See, for example, Booth and Smith (1986), Beatty and Ritter (1986) and Carter and Manaster (1990).

${ }^{37}$ Fernando et al. (2005) argue that if underwriter choice is a two-sided matching, higher underwriter reputation may not be associated with a higher probability of winning a deal. This would only be true for high reputation issuers.

${ }^{38}$ See Drucker and Puri (2005) for a discussion of the links between commercial loans and underwriting deals.
} 
Table 7 Underwriter reputation and underwriter-issuer relationship variables

\begin{tabular}{|c|c|c|c|c|c|c|c|}
\hline \multirow[b]{2}{*}{ Panel A: Equity Covered } & \multicolumn{3}{|c|}{ Winner } & \multicolumn{4}{|l|}{ Loser } \\
\hline & Obs & Mean & Std Dev & Obs & Mean & Std Dev & $\mathrm{t}$ \\
\hline Bank's share of REIT's equity deals & 473 & 0.437 & 0.423 & 1826 & 0.106 & 0.253 & 21.71 \\
\hline Bank's share of REIT's syndicated loans & 473 & 0.154 & 0.313 & 1826 & 0.063 & 0.19 & 8.01 \\
\hline Bank's share of REIT's debt deals & 473 & 0.036 & 0.141 & 1826 & 0.02 & 0.108 & 2.53 \\
\hline Bank's previous year equity market share & 473 & 0.136 & 0.12 & 1826 & 0.096 & 0.088 & 8.08 \\
\hline Bank's previous year debt market share & 473 & 0.113 & 0.119 & 1826 & 0.081 & 0.092 & 6.17 \\
\hline Bank's previous year syndicated loan market share & 473 & 0.015 & 0.032 & 1826 & 0.019 & 0.047 & 1.81 \\
\hline \multicolumn{8}{|l|}{ Panel B: Equity Not Covered } \\
\hline Bank's share of REIT's equity deals & 412 & 0.316 & 0.394 & 5207 & 0.023 & 0.124 & 35.71 \\
\hline Bank's share of REIT's syndicated loans & 412 & 0.11 & 0.276 & 5207 & 0.015 & 0.096 & 15.6 \\
\hline Bank's share of REIT's debt deals & 412 & 0.037 & 0.167 & 5207 & 0.01 & 0.082 & 5.79 \\
\hline Bank's previous year equity market share & 412 & 0.089 & 0.1 & 5207 & 0.082 & 0.076 & 1.69 \\
\hline Bank's previous year debt market share & 412 & 0.069 & 0.104 & 5207 & 0.071 & 0.087 & 0.32 \\
\hline Bank's previous year syndicated loan market share & 412 & 0.011 & 0.033 & 5207 & 0.02 & 0.052 & 3.28 \\
\hline \multicolumn{8}{|l|}{ Panel C: Debt Covered } \\
\hline Bank's share of REIT's equity deals & 499 & 0.288 & 0.389 & 2290 & 0.103 & 0.252 & 13.27 \\
\hline Bank's share of REIT's syndicated loans & 499 & 0.321 & 0.368 & 2290 & 0.086 & 0.201 & 19.83 \\
\hline Bank's share of REIT's debt deals & 499 & 0.094 & 0.236 & 2290 & 0.038 & 0.156 & 6.56 \\
\hline Bank's previous year equity market share & 499 & 0.115 & 0.122 & 2290 & 0.103 & 0.105 & 2.3 \\
\hline Bank's previous year debt market share & 499 & 0.152 & 0.111 & 2290 & 0.105 & 0.096 & 9.71 \\
\hline Bank's previous year syndicated loan market share & 499 & 0.05 & 0.073 & 2290 & 0.035 & 0.065 & 4.54 \\
\hline \multicolumn{8}{|l|}{ Panel D: Debt Not Covered } \\
\hline Bank's share of REIT's equity deals & 435 & 0.173 & 0.329 & 3125 & 0.049 & 0.182 & 11.8 \\
\hline Bank's share of REIT's syndicated loans & 435 & 0.236 & 0.316 & 3125 & 0.043 & 0.148 & 21.31 \\
\hline Bank's share of REIT's debt deals & 435 & 0.121 & 0.282 & 3125 & 0.016 & 0.104 & 14.89 \\
\hline Bank's previous year equity market share & 435 & 0.079 & 0.111 & 3125 & 0.086 & 0.096 & 1.48 \\
\hline Bank's previous year debt market share & 435 & 0.131 & 0.11 & 3125 & 0.106 & 0.095 & 5.09 \\
\hline Bank's previous year syndicated loan market share & 435 & 0.058 & 0.077 & 3125 & 0.041 & 0.068 & 4.88 \\
\hline
\end{tabular}

Table reports descriptive statistics for the variables measuring the Bank-Issuer relationship. Panels A and $\mathrm{B}$ report statistics for equity deals with and without analyst coverage. Panels $\mathrm{C}$ and $\mathrm{D}$ report statistics for debt deals with and without analyst coverage

\section{The Benefits of Coverage $Z_{C}$}

The decision of a brokerage to cover a given firm is a strategic one related to the costs and benefits of providing coverage. It is well known that banks are more likely to provide coverage for firms that they already have a relationship with. ${ }^{39}$ For this reason Underwriting Relationship and Banking Relationship are included in the Brokerage Coverage equation. Underwriting Relationship is a dummy variable taking the value one if the underwriter has underwritten any security issuance by the firm in the past three years. Banking Relationship is a dummy variable taking the value one if the investment bank has had a syndicated loan relationship with the firm in the last three years. O'Brien and Bhushan (1990)

\footnotetext{
${ }^{39}$ See, for example, Michaely and Womack (1999), Burch et al. (2005) and Ellis et al. (2005).
} 
show that the size of the firm is also likely to be a key determinant of coverage. As such, Size is also included in the Analyst Coverage equation.

Since brokerages generate revenue from commissions, firms that have actively traded equity are more likely to receive research coverage from brokerages than firms that have little trading activity. To capture this we include Time to Turnover in the Analyst Behavior equation. Industry Coverage is also included in the coverage equation since brokerages that are specialists in real estate are more likely to cover any given REIT. A given brokerage is also more likely to cover a firm if it is covered by other brokerages, so we also include Competitor Coverage, the number of competitors covering the firm.

Firms that raise capital more aggressively are likely to attract more interest from investors and as such are more likely to be covered by a brokerage. We include Past Deals to capture this effect. If the fees from the deal are high, especially compared to the bank's prior year fees, a brokerage might be more inclined to cover a firm. To control for this we include Fee to Last. Finally, we control for underwriter reputation.

\section{Results}

Table 8 reports estimation results for the Analyst Behavior equation when analyst behavior is measured using the relative analyst price. The Analyst Behavior equation is estimated over the 1996 to 2004 period using the maximum likelihood estimation (MLE) version of Heckman (1979).

In general, the results reported in Table 8 are consistent with a priori expectations. Strong past underwriting and banking relationships are associated with relatively lower optimism, while the potential benefits from the deal, measured by deal proceeds and fee to last year's fee revenue, tend to have a positive effect on optimism. Interestingly, underwriter reputation has strong positive effect on optimism.

The characteristics of the analyst are also a key determinant of the analyst's optimism. All Star analysts tend to be less optimistic, consistent with the hypothesis that they would be unwilling to trade their hard earned reputation for optimistic coverage. Furthermore, analysts who are specialists in the REIT industry, as measured by the percentage of the industry that they cover, tend to be less optimistic also. This is consistent with specialist analysts facing higher costs in providing optimistic coverage.

Finally, the characteristics of the firm also play an important role in explaining analyst optimism. As expected, firm size has a negative impact on analyst optimism. This is consistent with the hypothesis that, all else equal, the potential costs of hyping are larger for larger firms. These costs should also be higher for firms that have greater trading activity. The significantly positive coefficient on Time to 
Turnover is consistent with this hypothesis. The positive and significant coefficient on Volatility suggests that higher firm volatility has a positive effect on analyst optimism. This is consistent with the hypothesis that higher firm volatility reduces the costs that the analyst faces in explaining potentially optimistic research. Finally, firms that raise more capital appear to receive more optimistic coverage.

Table 8 Analyst behavior: relative analyst price

\begin{tabular}{|c|c|c|}
\hline Variable & Equity & Debt \\
\hline \multirow[t]{2}{*}{ Bank's share of firm's previous 5-year equity deals } & -0.078 & -0.007 \\
\hline & -6.76 & -0.66 \\
\hline \multirow[t]{2}{*}{ Bank's share of firm's previous 5-year debt deals } & -0.056 & -0.046 \\
\hline & -3.89 & -4.49 \\
\hline \multirow[t]{2}{*}{ Bank's share of firm's previous 5-year syndicated loans } & -0.08 & -0.014 \\
\hline & -3.12 & -0.87 \\
\hline \multirow[t]{2}{*}{ Deal Proceeds } & 0.003 & 0.008 \\
\hline & 0.8 & 4.53 \\
\hline \multirow[t]{2}{*}{ All Star } & -0.016 & 0 \\
\hline & -2.63 & -0.09 \\
\hline \multirow[t]{2}{*}{ Loyalty } & 0.005 & 0.03 \\
\hline & 0.56 & 4.46 \\
\hline \multirow[t]{2}{*}{ Percentage of Industry covered by analyst } & -0.435 & -0.409 \\
\hline & -11.15 & -13.35 \\
\hline \multirow[t]{2}{*}{ Turnover } & 0.033 & 0.04 \\
\hline & 8.26 & 9.81 \\
\hline \multirow[t]{2}{*}{ Past Deal Pool } & 0.011 & -0.003 \\
\hline & 4.1 & -1.04 \\
\hline \multirow[t]{2}{*}{ Firm Return Volatility } & 0.582 & 0.53 \\
\hline & 4.4 & 4.78 \\
\hline \multirow[t]{2}{*}{ Fee to Last } & 0.043 & 0.077 \\
\hline & 1.74 & 4.26 \\
\hline \multirow[t]{2}{*}{ Size } & -0.111 & -0.093 \\
\hline & -18.91 & -18.31 \\
\hline \multirow[t]{2}{*}{ Reputation } & 0.323 & 0.223 \\
\hline & 5.3 & 4.91 \\
\hline Observations & 7918 & 6349 \\
\hline Censored Observations & 5815 & 3755 \\
\hline Wald Test: All coefficients $=0$ & 753.663 & 817.59 \\
\hline Staiger and Stock Strong Instruments F Test & 89.08 & 104.53 \\
\hline Correlation between analyst and coverage equations $\rho$ & -0.963 & -0.968 \\
\hline Test of $\rho=0$ & 450.783 & 666.608 \\
\hline$\lambda$ & -0.224 & -0.195 \\
\hline Std Error $\lambda$ & 0.005 & 0.004 \\
\hline
\end{tabular}

Table reports estimation results for Analyst Behavior equation when the dependent variable is the relative analyst price. The sample is split between equity and debt deals. Estimation is performed using a MLE version of Heckman (1979). Data cover the period 1996 to 2004. Results for the selection equation are omitted along with the constant term. t-statistics are in italics

The fitted value from the Analyst Behavior equation is the key variable of interest in the Underwriter Choice equation. As such, the strength of the instruments used to proxy for analyst 
behavior is a cause for concern. Staiger and Stock (1997) show that weak instruments can cause misleading asymptotic inference in second stage regressions. As a rule of thumb, they suggest that strong instruments should have a joint $\mathrm{F}$ test greater than 10 . For both debt and equity deals, the instruments are very strong with $\mathrm{F}$ statistics of 89.08 and 104.53 respectively. This indicates that weak instruments is unlikely to be a problem in the second stage regression.

Table 9 reports estimation results for the Underwriter Choice equation, when analyst behavior is measured using the relative analyst price. The first two columns report results for equity deals, while the second two columns report results for debt deals. Covered columns refer to those deals for which analyst coverage occurs, while Not Covered columns refer to deals without coverage.

Table 9 Underwriter choice: relative analyst price

\begin{tabular}{|c|c|c|c|c|}
\hline \multirow[b]{2}{*}{ Variable } & \multicolumn{2}{|c|}{ Equity Deals } & \multicolumn{2}{|l|}{ Debt Deals } \\
\hline & Covered & Not Covered & Covered & Not Covered \\
\hline \multirow[t]{2}{*}{ Analyst Behavior } & 1.404 & & 1.104 & \\
\hline & 3.25 & & 1.87 & \\
\hline \multirow{2}{*}{$\begin{array}{l}\text { Bank's share of firm's previous 5-year } \\
\text { equity deals }\end{array}$} & 1.196 & 2.406 & 0.687 & 0.691 \\
\hline & 10.12 & 18.8 & 5.49 & 5.03 \\
\hline \multirow{2}{*}{$\begin{array}{l}\text { Bank's share of firm's previous 5-year } \\
\text { debt deals }\end{array}$} & 0.13 & 0.613 & 1.19 & 1.635 \\
\hline & 0.87 & 2.8 & 9.83 & 13.01 \\
\hline \multirow{2}{*}{$\begin{array}{l}\text { Bank's share of firm's previous 5-year } \\
\text { syndicated loans }\end{array}$} & 0.258 & 1.001 & 0.394 & 1.397 \\
\hline & 1.07 & 3.84 & 2.55 & 9.3 \\
\hline \multirow[t]{2}{*}{ Bank's previous year equity market share } & 0.373 & -0.681 & -0.482 & -1.182 \\
\hline & 0.64 & -1.47 & -1.19 & -3.15 \\
\hline \multirow[t]{2}{*}{ Bank's previous year debt market share } & -0.275 & -0.488 & 0.938 & 0.296 \\
\hline & -0.54 & -1.15 & 2.36 & 0.85 \\
\hline \multirow{2}{*}{$\begin{array}{l}\text { Bank's previous year syndicated loan } \\
\text { market share }\end{array}$} & -1.207 & -1.926 & 1.429 & 0.069 \\
\hline & -1.33 & -2.79 & 2.76 & 0.15 \\
\hline \multirow[t]{2}{*}{ All Star } & 0.068 & -0.194 & -0.066 & -0.23 \\
\hline & 0.89 & -3.01 & -0.89 & -3.03 \\
\hline Observations & 7918 & 7918 & 6349 & 6349 \\
\hline Censored Observations & 5815 & 2103 & 3755 & 2594 \\
\hline Wald Test: All coefficients $=0$ & 172.328 & 498.165 & 324.556 & 430.701 \\
\hline $\begin{array}{l}\text { Correlation between analyst and coverage } \\
\text { equations } \rho\end{array}$ & -0.211 & -0.066 & -0.279 & -0.157 \\
\hline Test of $\rho=0$ & 3.161 & 0.303 & 3.009 & 3.103 \\
\hline
\end{tabular}

Table reports estimation for the Underwriter Choice equation. The dependent variable is equal to one if the underwriter won the underwriting deal and zero otherwise. Estimation is performed using the Heckmanadjusted probit model of Van De Ven and Van Pragg (1981). Covered refers to case where coverage occurs and analyst behavior is the fitted value from the analyst behavior equation using relative analyst price as the dependent variable (see Table 8). Not covered refers to the case where analyst behavior is not observed. The sample is split between debt and equity deals. Data cover the period 1996 to 2004. Murphy and Topel (1985) t-statistics are in italics

The key value in Table 9 is the coefficient on Analyst Behavior. For both equity and debt deals, the coefficient is positive, however, it is only significant for equity deals. This differs from the prior 
literature, which finds an ambiguous relationship between analyst behavior and underwriter choice. In terms of marginal effects, the effect of analyst behavior is quite significant for equity deals. Consider a simple example with two analysts, the first issuing a target price of $\$ 105$ and the second issuing a target price of $\$ 115$. If the current price is $\$ 100$, then by increasing her target price to $\$ 115$, the first analyst increases her bank's probability of winning the deal by roughly $9 \%$. As a comparison, for equity deals, a one standard deviation increase in past firm equity underwritten leads to a $5 \%$ increase in the probability of winning an underwriting deal. ${ }^{40}$

Consistent with the prior literature on underwriter relationships, past underwriting relationships also play an important role in current underwriter choice. For equity deals, strong past equity underwriting relationships appear to be the most crucial factor driving underwriter choice. For debt deals, it appears that any past underwriting relationship or past banking relationship is important.

For deals where analysts' coverage was not provided, banking relationships appear to play a more important role. For both debt and equity deals, strong past banking relationships lead to a greater probability of winning an underwriting deal. Given that a key determinant of coverage is firm size, it is logical to expect that small firms would view the provider of their loans as a low search cost candidate to underwrite their security issuance.

Table 10 reports stand-alone probit estimation of the strategic coverage decision. Once again we split the sample by security type. Consistent with Krigman et al. (2001) and Ellis et al. (2005), past underwriting relationships increase the likelihood of coverage. Examining marginal effects, for equity and debt deals a past underwriting relationship increases the likelihood of coverage by $34 \%$ and $17 \%$ respectively. A past banking relationship increases the probability of coverage by approximately $9 \%$ for both debt and equity deals. The other main determinant of coverage appears to be size. A one standard deviation increase in firm size results in a $10 \%$ increase in the probability of coverage for equity deals and a $20 \%$ increase for debt deals. Overall the results of Table 10 indicate that the coverage decision is, as expected, not random, lending support to the use of the Heckman (1979) based econometric techniques.

As a robustness check, we repeat the analysis using relative analyst recommendation as the measure of analyst behavior. Table 11 reports results for the Analyst Behavior equation, while Table 12 reports the Underwriter Choice equation. The results for the Analyst Behavior equation are similar to those using target prices, although the fit of the model is not as good. Examining the Underwriter Choice

\footnotetext{
${ }^{40}$ Combining all deals together in one estimation leads to results very similar to, although slightly weaker than, the equity deal sample.
} 
equation, we see that the evidence for analyst behavior affecting underwriter choice is mixed. For equity deals there is no evidence that analyst behavior plays a role in underwriter choice. For debt deals, however, analyst behavior has a positive and significant coefficient. This positive result differs from prior studies, which find an ambiguous relationship. This is most likely due to the differing definition of analyst behavior we employ. When we replicate the analysis with the analyst behavior measure used by Ljungqvist et al. (2006) we find mixed results. For equity deals we find a positive coefficient, while for debt deals the coefficient is negative. However, assessing statistical significance is difficult since in both cases the estimation has very weak instruments. ${ }^{41}$

Table 10 Brokerage coverage equation

\begin{tabular}{|c|c|c|}
\hline Variable & Equity & Debt \\
\hline \multirow[t]{2}{*}{ Underwriter Relationship } & 1.114 & 0.542 \\
\hline & 25.56 & 13.34 \\
\hline \multirow[t]{2}{*}{ Banking Relationship } & 0.343 & 0.155 \\
\hline & 3.73 & 2.22 \\
\hline \multirow[t]{2}{*}{ Size } & 0.382 & 0.523 \\
\hline & 13.33 & 16.34 \\
\hline \multirow[t]{2}{*}{ Industry Coverage } & 1.958 & 3.619 \\
\hline & 10.97 & 20.93 \\
\hline \multirow[t]{2}{*}{ Competitor Coverage } & 0.027 & 0.039 \\
\hline & 2.34 & 3.5 \\
\hline \multirow[t]{2}{*}{ Time to Turnover } & -0.114 & -0.140 \\
\hline & -6.25 & -5.9 \\
\hline \multirow[t]{2}{*}{ Past Deals } & -0.023 & 0.021 \\
\hline & -1.79 & 1.38 \\
\hline \multirow[t]{2}{*}{ Fee to Last } & 0.186 & -0.321 \\
\hline & 1.72 & -3.32 \\
\hline \multirow[t]{2}{*}{ Reputation } & -1.747 & -2.481 \\
\hline & -6.41 & -9.86 \\
\hline Observations & 7918 & 6349 \\
\hline Pseudo- $\mathrm{R}^{2}$ & 0.2377 & 0.2276 \\
\hline
\end{tabular}

\section{Reconciling Target Prices and Recommendations}

Comparing Table 9 and Table 12, we see that the positive relation between analyst optimism and deal flow appears more statistically significant when analyst behavior is measured using target prices. Clearly, recommendations and prices should contain similar information, but target prices are

\footnotetext{
${ }^{41}$ These insignificant findings may be the result of the smaller size of our sample. Ljungqvistet al. (2006) have approximately 10 times the number of observations in their estimation.
} 
likely to be a better measure of analyst opinion than recommendations for several reasons. ${ }^{42}$ First, target prices are continuous and therefore allow a finer measure of analyst opinion. Second, target prices are not capped in how optimistic or pessimistic they can be. Henry Blodget's December 1998 prediction that Amazon.com would be worth $\$ 400$ per share within a year from its then $\$ 243$ per share, obviously sends a stronger signal than a Strong Buy. ${ }^{43}$

Table 11 Analyst behavior: relative analyst recommendation

\begin{tabular}{|c|c|c|}
\hline Variable & Equity & Debt \\
\hline \multirow[t]{2}{*}{ Bank's share of firm's previous 5-year equity deals } & -0.27 & 0.049 \\
\hline & -3.16 & 0.59 \\
\hline \multirow[t]{2}{*}{ Bank's share of firm's previous 5-year debt deals } & -0.324 & -0.125 \\
\hline & -2.82 & -1.47 \\
\hline \multirow[t]{2}{*}{ Bank's share of firm's previous 5-year syndicated loans } & -0.293 & -0.228 \\
\hline & -1.35 & -1.78 \\
\hline \multirow[t]{2}{*}{ Deal Proceeds } & -0.033 & 0.043 \\
\hline & -1.29 & 2.71 \\
\hline \multirow[t]{2}{*}{ All Star } & -0.262 & -0.197 \\
\hline & -5.69 & -4.47 \\
\hline \multirow[t]{2}{*}{ Loyalty } & 0.207 & 0.07 \\
\hline & 3.29 & 1.16 \\
\hline \multirow[t]{2}{*}{ Percentage of Industry covered by analyst } & -3.679 & -2.928 \\
\hline & -13.54 & -12.84 \\
\hline \multirow[t]{2}{*}{ Turnover } & 0.126 & 0.097 \\
\hline & 4.86 & 3.71 \\
\hline \multirow[t]{2}{*}{ Past Deal Pool } & 0.049 & 0.024 \\
\hline & 2.41 & 1.24 \\
\hline \multirow[t]{2}{*}{ Firm Return Volatility } & 2.977 & 1.973 \\
\hline & 2.86 & 2.33 \\
\hline \multirow[t]{2}{*}{ Fee to Last } & 0.34 & 0.029 \\
\hline & 1.85 & 0.21 \\
\hline \multirow[t]{2}{*}{ Size } & -0.516 & -0.302 \\
\hline & -12.39 & -7.85 \\
\hline \multirow[t]{2}{*}{ Reputation } & -0.135 & -0.345 \\
\hline & -0.34 & -1.06 \\
\hline Observations & 7918 & 6349 \\
\hline Censored Observations & 5616 & 3556 \\
\hline Wald Test: All coefficients $=0$ & 619.077 & 359.379 \\
\hline Staiger and Stock Strong Instruments F Test & 71.4 & 43.23 \\
\hline Correlation between analyst and coverage equations $\rho$ & -0.937 & -0.914 \\
\hline Test of $\rho=0$ & 271.22 & 260.83 \\
\hline$\lambda$ & -1.597 & -1.377 \\
\hline Std Error $\lambda$ & 0.049 & 0.046 \\
\hline
\end{tabular}

Table reports estimation results for Analyst Behavior equation when the dependent variable is the relative analyst recommendation. Estimation is performed using a MLE version of Heckman (1979). Data cover the period 1996 to 2004 . Results for the selection equation are omitted along with the constant term. $\mathrm{t}$-statistics are in italics

\footnotetext{
${ }^{42}$ See Brav and Lehavy (2003) for a discussion of recommendations versus target prices.

${ }^{43}$ See Cole (2001) for a discussion of the incident.
} 
Finally, comparing recommendations across brokerages is problematic. ${ }^{44}$ Recommendations are by their nature a discrete measure of analyst opinion. Comparing recommendations across analysts would not be a problem if the number of potential categories for each analyst was the same. This is, however, not the case. In general, brokerages have either a three, four or five recommendation system. A three recommendation system is Buy/Hold/Sell, a four recommendation system is typically Strong Buy/Buy/Hold/Sell and a five recommendation is Strong Buy/Buy/Hold/Sell/ Strong Sell.

Table 12 Underwriter choice: relative analyst recommendation

\begin{tabular}{|c|c|c|c|c|}
\hline \multirow[b]{2}{*}{ Variable } & \multicolumn{2}{|c|}{ Equity Deals } & \multicolumn{2}{|l|}{ Debt Deals } \\
\hline & Covered & Not Covered & Covered & Not Covered \\
\hline \multirow[t]{2}{*}{ Analyst Behavior } & 0.069 & & 0.404 & \\
\hline & 0.91 & & 4.76 & \\
\hline \multirow{2}{*}{$\begin{array}{l}\text { Bank's share of firm's previous 5-year } \\
\text { equity deals }\end{array}$} & 1.525 & 2.189 & 0.518 & 0.711 \\
\hline & 15.3 & 16 & 4.5 & 4.69 \\
\hline \multirow{2}{*}{$\begin{array}{l}\text { Bank's share of firm's previous 5-year } \\
\text { debt deals }\end{array}$} & 0.203 & 0.643 & 1.11 & 1.599 \\
\hline & 1.39 & 2.85 & 9.03 & 11.12 \\
\hline \multirow{2}{*}{$\begin{array}{l}\text { Bank's share of firm's previous 5-year } \\
\text { syndicated loans }\end{array}$} & 0.728 & 0.405 & 0.416 & 1.315 \\
\hline & 2.9 & 1.25 & 2.87 & 7.32 \\
\hline \multirow[t]{2}{*}{ Bank's previous year equity market share } & 0.775 & -0.545 & -0.506 & -1.171 \\
\hline & 1.58 & -1.05 & -1.35 & -2.7 \\
\hline \multirow[t]{2}{*}{ Bank's previous year debt market share } & -0.331 & -0.776 & 0.937 & 0.213 \\
\hline & -0.67 & -1.76 & 2.56 & 0.59 \\
\hline \multirow{2}{*}{$\begin{array}{l}\text { Bank's previous year syndicated loan } \\
\text { market share }\end{array}$} & -0.564 & -2.074 & 1.063 & 0.371 \\
\hline & -0.63 & -2.96 & 2.21 & 0.79 \\
\hline \multirow[t]{2}{*}{ All Star } & -0.031 & -0.136 & 0.076 & -0.228 \\
\hline & -0.4 & -2.24 & 1.03 & -3.05 \\
\hline Observations & 7918 & 7918 & 6349 & 6349 \\
\hline Censored Observations & 5616 & 2302 & 3556 & 2793 \\
\hline Wald Test: All coefficients $=0$ & 332.11 & 301.577 & 280.901 & 255.611 \\
\hline $\begin{array}{l}\text { Correlation between analyst and coverage } \\
\text { equations } \rho\end{array}$ & 0.198 & -0.005 & -0.473 & 0.134 \\
\hline Test of $\rho=0$ & 1.79 & 0 & 10.78 & 0.66 \\
\hline
\end{tabular}

Table reports estimation for the Underwriter Choice equation. The dependent variable is equal to one if the underwriter won the underwriting deal and zero otherwise. Estimation is performed using the Heckmanadjusted probit model of Van De Ven and Van Pragg (1981). Covered refers to case where coverage occurs and analyst behavior is the fitted value from the analyst behavior equation using relative analyst recommendation as the dependent variable (see Table 11). Not covered refers to the case where analyst behavior is not observed. The sample is split between debt and equity deals. Data cover the period 1996 to 2004. Murphy and Topel (1985) t-statistics are in italics

Obviously some judgment is required when comparing a Buy recommendation from a three recommendation broker with a Buy from a five recommendation broker. First Call does this by taking the five recommendation system as a bench mark and assigning a value of 1 to a Strong Buy, 2 to a Buy and so on. ${ }^{45}$ A four recommendation system is rated 1 for Strong Buy, 2 for Buy, 3 for Hold and 5 for Sell.

\footnotetext{
${ }^{44}$ The Securities and Exchange Commission makes direct reference to this on their investor education web page: http://www.sec.gov/investor/pubs/analysts.htm.

${ }^{45}$ In the estimation we reverse this so a Strong Buy is rated 5.
} 
A three recommendation system is 1 for a Buy, 3 for a Hold and 5 for a Sell. ${ }^{46}$ This matching process introduces noise into any metric based on the recommendations data.

\section{Robustness Checks}

As a robustness check we partition the sample along two dimensions. First, we split the sample based on the fees generated from the deal. The High Fee group consists of deals with fees greater than one million dollars, while the Low Fee group contains all deals below one million dollars. One would expect that if analyst behavior is driven by career concerns, then analyst behavior should play a more important role for the High Fee group than the Low Fee group. Table 13 shows that this is the case. The coefficient on analyst behavior for the Low Fee group is insignificant, while it is significantly positive for the High Fee group. This result also holds in equity and debt sub-sample. So although in aggregate analyst behavior does not appear to affect underwriter choice, in the sub-sample of debt deals where one would expect incentives to be the greatest, analyst behavior has a positive effect on underwriter choice. This result can be reconciled with the full sample results by noting that debt deals have a much lower fee structure than equity deals. This results in the full sample being dominated by Low Fee deals for debt deals, while the full sample for equity deals is dominated by High Fee deals.

We also split the sample into deals occurring before and after 2001. The post 2001 sample coincides with increased scrutiny by regulators of possible conflicts of interest between analysts and investment banks. This increased regulatory pressure suggests that analyst behavior may play a less important role during this period. Examining Table 14, analyst behavior has a positive and significant coefficient in both sub-samples. The magnitude of the coefficient is, however, roughly half the size in latter sub-sample. So overall there is some evidence to suggest that increased regulatory interest has decreased the role that analysts play in underwriter choice.

The set of underwriters competing for a given deal is different between this study and that of Ljungqvist et al. (2006). We replicate our analysis using the characterization of competition used in the Ljungqvist et al. (2006) study. Table 15 reports these results. For both equity and debt deals we find, consistent with Ljungqvist et al. (2006), an insignificant relationship between analyst behavior and underwriter choice. A potential explanation that reconciles this result with our results in Table 9 comes from the noise that the Ljungqvist et al. (2006) selection method adds to our sample. Ljungqvist et al. (2006) includes a far greater number of underwriters competing for every deal. This means that

\footnotetext{
${ }^{46}$ This process is also used by $\mathrm{I} / \mathrm{B} / \mathrm{E} / \mathrm{S}$, so although previous studies have used that data, the problem of comparing analyst recommendations remains.
} 
underwriters like Thomas Weisel, which have never underwritten a REIT deal, have no past relationship with the firm, no past underwriting market share and no analyst coverage are considered to be competing for deals. So although at the firm universe level it may appear that they would compete for the average deal, at the industry level competition can look very different.

Table 13 Underwriter choice: fee sub-samples

\begin{tabular}{|c|c|c|c|c|}
\hline \multirow[b]{2}{*}{ Variable } & \multicolumn{2}{|l|}{ High Fee } & \multicolumn{2}{|l|}{ Low Fee } \\
\hline & Covered & Not Covered & Covered & Not Covered \\
\hline \multirow[t]{2}{*}{ Analyst Behavior } & 1.667 & & 1.033 & \\
\hline & 3.63 & & 1.89 & \\
\hline \multirow{2}{*}{$\begin{array}{l}\text { Bank's share of firm's previous 5-year } \\
\text { equity deals }\end{array}$} & 1.267 & 2.226 & 0.664 & 0.876 \\
\hline & 10.97 & 17.62 & 5.29 & 6.18 \\
\hline \multirow{2}{*}{$\begin{array}{l}\text { Bank's share of firm's previous 5-year } \\
\text { debt deals }\end{array}$} & 0.396 & 0.895 & 1.098 & 1.647 \\
\hline & 2.89 & 4.6 & 8.57 & 12.46 \\
\hline \multirow{2}{*}{$\begin{array}{l}\text { Bank's share of firm's previous 5-year } \\
\text { syndicated loans }\end{array}$} & 0.513 & 1.207 & 0.247 & 1.413 \\
\hline & 2.75 & 5.91 & 1.38 & 8.59 \\
\hline \multirow[t]{2}{*}{ Bank's previous year equity market share } & 0.294 & -0.182 & -0.807 & -2.273 \\
\hline & 0.64 & -0.44 & -1.69 & -5.17 \\
\hline \multirow[t]{2}{*}{ Bank's previous year debt market share } & 0.495 & -0.227 & 0.021 & 0.241 \\
\hline & 1.15 & -0.6 & 0.05 & 0.68 \\
\hline \multirow{2}{*}{$\begin{array}{l}\text { Bank's previous year syndicated loan } \\
\text { market share }\end{array}$} & 0.067 & -0.188 & 1.198 & -0.669 \\
\hline & 0.1 & -0.35 & 2.02 & -1.39 \\
\hline \multirow[t]{2}{*}{ All Star } & -0.012 & -0.143 & -0.019 & -0.267 \\
\hline & -0.17 & -2.17 & -0.24 & -3.73 \\
\hline Observations & 7849 & 7849 & 6418 & 6418 \\
\hline Censored Observations & 5459 & 2390 & 4111 & 2307 \\
\hline Wald Test: All coefficients $=0$ & 261.403 & 461.244 & 206.219 & 413.077 \\
\hline $\begin{array}{l}\text { Correlation between analyst and coverage } \\
\text { equations } \rho\end{array}$ & -0.263 & 0.05 & -0.06 & -0.233 \\
\hline Test of $\rho=0$ & 4.311 & 0.177 & 0.152 & 7.963 \\
\hline
\end{tabular}

Table reports estimation for the Underwriter Choice equation. The dependent variable is equal to one if the underwriter won the underwriting deal and zero otherwise. Estimation is performed using the Heckman adjusted probit model of Van De Ven and Van Pragg (1981). Covered refers to the case where coverage occurs and analyst behavior is the fitted value from the analyst behavior equation using relative analyst price as the dependent variable. Not covered refers to the case where analyst behavior is not observed. Low Fee are deals with fees less than $\$ 1$ million, High Fee are deal with greater than $\$ 1$ million in fees. The estimation period is 1996 to 2004. Murphy and Topel (1985) t-statistics are in italics

Another possible rationale for our finding that winning analysts have more optimistic estimates of stock prices is that these analysts are more familiar with the firms and thus are more confident in their ability to forecast future prices. ${ }^{47}$ We tested this hypothesis by calculating the percentage stock price forecast error over the following one-year period. Specifically, we compute the difference between

\footnotetext{
${ }^{47}$ We are grateful to our discussant at the DePaul REIT Symposium, Jim Booth, for this observation.
} 
analyst's forecast stock price and the actual stock price one year in the future, divided by the stock price at the time the forecast was made. This analysis revealed no significant differences between winning and losing analysts. This result holds for debt and equity deals and for the pre and post 2001 periods. For example, for equity deals, the winning analysts' average error was $3.11 \%$ versus $3.10 \%$ for losing analysts. One interesting result was the difference between forecast bias prior to and post 2001. Prior to 2001 the forecast errors for winners and non-winners was $17.1 \%$ and $15.5 \%$ respectively; post 2001 the corresponding figures were $-13.1 \%$ and $-15.6 \%$ respectively. These data indicate that one consequence of the increased regulation was to make all analysts much more conservative in their forecasts.

Table 14 Underwriter choice: time sub-samples

\begin{tabular}{|c|c|c|c|c|}
\hline \multirow[b]{2}{*}{ Variable } & \multicolumn{2}{|l|}{ Pre 2001} & \multicolumn{2}{|l|}{ Post 2001} \\
\hline & Covered & Not Covered & Covered & Not Covered \\
\hline \multirow[t]{2}{*}{ Analyst Behavior } & 5.772 & & 2.589 & \\
\hline & 6.2 & & 4.9 & \\
\hline \multirow{2}{*}{$\begin{array}{l}\text { Bank's share of firm's previous 5-year } \\
\text { equity deals }\end{array}$} & 0.884 & 1.557 & 1.027 & 1.576 \\
\hline & 6.94 & 14.9 & 8.24 & 8.39 \\
\hline \multirow{2}{*}{$\begin{array}{l}\text { Bank's share of firm's previous 5-year } \\
\text { debt deals }\end{array}$} & 0.385 & 1.329 & 1.243 & 1.238 \\
\hline & 3.3 & 10.85 & 8.2 & 5.24 \\
\hline \multirow{2}{*}{$\begin{array}{l}\text { Bank's share of firm's previous 5-year } \\
\text { syndicated loans }\end{array}$} & 0.2 & 1.668 & 0.188 & 1.078 \\
\hline & 0.94 & 7.55 & 1.18 & 6.56 \\
\hline \multirow[t]{2}{*}{ Bank's previous year equity market share } & -0.321 & -1.984 & 0.443 & -0.839 \\
\hline & -0.7 & -5.49 & 0.88 & -1.37 \\
\hline \multirow[t]{2}{*}{ Bank's previous year debt market share } & 1.131 & 0.869 & -0.201 & -1.777 \\
\hline & 3.14 & 2.99 & -0.32 & -2.51 \\
\hline \multirow{2}{*}{$\begin{array}{l}\text { Bank's previous year syndicated loan } \\
\text { market share }\end{array}$} & 0.882 & -0.8 & 0.598 & 1.24 \\
\hline & 1.03 & -1.46 & 1.05 & 2.37 \\
\hline \multirow[t]{2}{*}{ All Star } & -0.233 & -0.051 & -0.046 & -0.286 \\
\hline & -2.82 & -0.82 & -0.56 & -3.68 \\
\hline Observations & 7970 & 7970 & 6297 & 6297 \\
\hline Censored Observations & 5777 & 2193 & 3793 & 2504 \\
\hline Wald Test: All coefficients $=0$ & 273.411 & 581.423 & 213.368 & 154.18 \\
\hline $\begin{array}{l}\text { Correlation between analyst and coverage } \\
\text { equations } \rho\end{array}$ & -0.473 & -0.246 & -0.242 & 0.207 \\
\hline Test of $\rho=0$ & 16.114 & 9.459 & 2.256 & 2.418 \\
\hline
\end{tabular}

Table reports estimation for the Underwriter Choice equation. The dependent variable is equal to one if the underwriter won the underwriting deal and zero otherwise. Estimation is performed using the Heckman adjusted probit model of Van De Ven and Van Pragg (1981). Covered refers to the case where coverage occurs and analyst behavior is the fitted value from the analyst behavior equation using relative analyst price as the dependent variable. Not covered refers to the case where analyst behavior is not observed. Pre 2001 refers to deals occurring before 2001, Post 2001 refers to deals occurring after January 2001. Murphy and Topel (1985) t-statistics are in italics 
Finally, the competitive landscape has changed considerably during the sample period. At the beginning of the sample, Merrill Lynch was the dominant underwriter in the market. It is possible that the dominant role that Merrill Lynch played in the sample is driving our result. To examine this, we replicated the estimation dropping Merrill Lynch from our sample with the result remaining similar to those previously reported.

Table 15 Underwriter choice: Ljungqvist et al. (2006) underwriter sample

\begin{tabular}{|c|c|c|c|c|}
\hline \multirow[b]{2}{*}{ Variable } & \multicolumn{2}{|c|}{ Equity Deals } & \multicolumn{2}{|l|}{ Debt Deals } \\
\hline & Covered & Not Covered & Covered & Not Covered \\
\hline \multirow[t]{2}{*}{ Analyst Behavior } & 0.526 & & 1.132 & \\
\hline & 0.99 & & 1.97 & \\
\hline \multirow{2}{*}{$\begin{array}{l}\text { Bank's share of firm's previous 5-year } \\
\text { equity deals }\end{array}$} & 1.323 & 2.283 & 0.574 & 0.446 \\
\hline & 11.63 & 18.75 & 4.77 & 3.07 \\
\hline \multirow{2}{*}{$\begin{array}{l}\text { Bank's share of firm's previous 5-year } \\
\text { debt deals }\end{array}$} & 0.106 & 0.453 & 1.169 & 1.687 \\
\hline & 0.72 & 2.23 & 9.45 & 14.05 \\
\hline \multirow{2}{*}{$\begin{array}{l}\text { Bank's share of firm's previous 5-year } \\
\text { syndicated loans }\end{array}$} & 0 & 0.707 & 0.528 & 1.147 \\
\hline & 0 & 3.71 & 3.52 & 9.11 \\
\hline \multirow[t]{2}{*}{ Bank's previous year equity market share } & 2.053 & 1.987 & -0.049 & -0.248 \\
\hline & 3.5 & 4.45 & -0.12 & -0.63 \\
\hline \multirow[t]{2}{*}{ Bank's previous year debt market share } & -0.761 & -0.31 & 1.663 & 3.303 \\
\hline & -1.46 & -0.63 & 4.42 & 9.8 \\
\hline \multirow{2}{*}{$\begin{array}{l}\text { Bank's previous year syndicated loan } \\
\text { market share }\end{array}$} & -0.253 & -1.175 & 2.175 & 2.669 \\
\hline & -0.28 & -1.66 & 4.43 & 6.16 \\
\hline \multirow[t]{2}{*}{ All Star } & 0.081 & 0.098 & 0.049 & 0.048 \\
\hline & 1.02 & 1.6 & 0.72 & 0.74 \\
\hline Observations & 18282 & 18282 & 17827 & 17827 \\
\hline Censored Observations & 15689 & 2593 & 14376 & 3451 \\
\hline Wald Test: All coefficients $=0$ & 223.395 & 554.306 & 390.547 & 754.878 \\
\hline $\begin{array}{l}\text { Correlation between analyst and coverage } \\
\text { equations } \rho\end{array}$ & -0.103 & 0.286 & -0.482 & 0.43 \\
\hline Test of $\rho=0$ & 0.671 & 12.339 & 9.351 & 29.958 \\
\hline
\end{tabular}

Table reports estimation for the Underwriter Choice equation. The dependent variable is equal to one if the underwriter won the underwriting deal and zero otherwise. Estimation is performed using the Heckmanadjusted probit model of Van De Ven and Van Pragg (1981). Covered refers to case where coverage occurs and analyst behavior is the fitted value from the analyst behavior equation using relative analyst price as the dependent variable. Not covered refers to the case where analyst behavior is not observed. The sample is split between debt and equity deals. Data cover the period 1996 to 2004. Murphy and Topel (1985) t-statistics are in italics

\section{Conclusions}

The role that analysts play in underwriter choice has received a great deal of recent attention from regulators and academics. The Global Settlement and a body of anecdotal evidence suggest that a 
positive relationship exists between analyst behavior and underwriter choice. That is, favorable analyst coverage increases an underwriter's probability of winning an underwriting deal.

Although the evidence in the popular press suggests a positive relationship between analyst behavior and underwriter choice, the empirical evidence on the issue is mixed. Ellis et al. (2005) find a positive relationship between the probability of switching underwriters and favorable analyst coverage. They, however, treat analyst behavior as exogenous. Ljungqvist et al. (2006) remedy this by accounting for both the endogeneity of analyst behavior and the strategic decision of the brokerage to provide research coverage. Examining a large cross-section of firms, they find that optimistic recommendations and upgrades are negatively associated with the probability of an underwriter winning an underwriting deal.

Examining a sample of debt and seasoned equity issuances by 161 equity REITs from 1996 to 2004, we find a significantly positive relationship between analyst behavior and underwriter choice for debt and equity deals that have fees greater than $\$ 1$ million. We also find evidence that suggests that post 2001, the role that analyst behavior plays in the choice of underwriter appears to have decreased. In this latter sample, the coefficient on analyst behavior has roughly halved for equity deals. While the coefficient for debt deals increases, this is due to larger fee deals coming to market in this sample compared to previously. This suggests that the increased scrutiny into analyst and investment bank conflicts of interest by regulators may be playing some role in underwriter choice.

The results of this paper differ greatly from the standard result in the prior literature that analyst behavior has no effect or possibly a negative effect on underwriter choice. ${ }^{48}$ This difference may arise from several sources. First, we employ an analyst behavior measure based on target prices rather than recommendations. Brav and Lehavy (2003) and Asquith et al. (2005) find empirically that target prices contain more information than recommendations. When we examine recommendations, our results are weaker.

Second, to obtain target prices the sample of firms examined in this study was limited to the equity REIT universe. This sample of firms has not been examined in before in the prior literature. Obviously this has great potential to drive the difference in results. However, we think this is unlikely. The economic unit of measurement in this study is an underwriting deal, and at this level, the deals in our study are very similar to those examined in other studies. The underwriters are the same; the deal sizes are comparable; and the fee structure is similar. So, although REITs have characteristics that

\footnotetext{
${ }^{48}$ See Clarke et al. (2007) and Ljungqvist et al. (2006).
} 
distinguish them from regular firms, in terms of the factors that are relevant for this analysis, they are very similar to regular firms.

Thus, our restricted sample of deals notwithstanding, we believe that this study makes a significant contribution to our understanding of the link between analyst behavior and firm underwriting choice. Our ability to increase the statistical power of the tests by using analyst price data, rather than just recommendations, and by more finely capturing competitive effects, in our opinion, is a reasonable tradeoff with reduced sample size. Further research is required to determine how general our results are.

\section{References}

Asquith, P., Mikhail, M. B., \& Au, A. S. (2005). Information content of equity analyst reports. Journal of Financial Economics, 75, 245-282.

Bartov, E., Givoly, D., \& Hayn, C. (2002). The rewards to meeting or beating earnings expectations. Journal of Accounting and Economics, 33, 173-204.

Beatty, R. P., \& Ritter, J. R. (1986). Investment banking, reputation, and the underpricing of initial public offerings. Journal of Financial Economics, 15, 213-232.

Booth, J. R., \& Smith, R. L. (1986). Capital raising, underwriting and the certification hypothesis. Journal of Financial Economics, 15, 261-281.

Boudry, W. I. (2010). An analysis of REIT dividend payout policy, Working paper, Stern, NYU.

Boudry, W. I., Kallberg, J. G., \& Liu, C. H. (2007). Fundamentals and institutional investment: The dynamics of REIT returns, Working Paper, Stern, NYU.

Boudry, W. I., Kallberg, J. G., \& Liu, C. H. (2010). An Analysis of REIT security issuance decisions. Real Estate Economics, 38, 91-120.

Bradshaw, M., Richardson, S. A., \& Sloan, R. G. (2003). Pump and dump: An empirical analysis of the relation between corporate financing activities and sell-side analyst research, Working Paper, University of Michigan.

Brav, A., \& Lehavy, R. (2003). An empirical analysis of analysts' target prices: short term informativeness and long term dynamics. Journal of Finance, 63, 1933-1967.

Burch, T. R., Nanda, V., \& Warther, V. (2005). Does it pay to be loyal? An empirical analysis of underwriting relationships and fees. Journal of Financial Economics, 77, 673-699.

Carter, R., \& Manaster, S. (1990). Initial public offerings and underwriter reputation. Journal of Finance, 45, 1045-1067. 
Clarke, J., Khorana, A., Patel, A., \& Rau, P. R. (2007). The impact of All-star analyst job changes on their coverage choices and investment banking deal flow. Journal of Financial Economics, 84(3), 713737.

Cole, B. M. (2001). The pied pipers of wall street. Princeton: Bloomberg.

Corwin, S., \& Schultz, P. (2005). The role of IPO underwriting syndicates: pricing, information production, and underwriting competition. Journal of Finance, 60, 443-486.

Das, S., Guo, R., \& Zhang, H. (2006). Analysts' selective coverage and subsequent performance of newly public firms. Journal of Finance, 61, 1159-1185.

Drucker, S., \& Puri, M. (2005). On the benefits of concurrent lending and underwriting. Journal of Finance, 77, 673-699.

Ellis, K., Michaely, R., \& O'Hara, M. (2005) Competition in investment banking: Proactive, reactive, or retaliatory? Working Paper, Cornell University.

Fang, L., \& Yasuda, A. (2009). The effectiveness of reputation as a disciplinary mechanism in sell-side research. Review of Financial Studies, 22, 3735-3777.

Fernando, C. S., Gatchev, V. A., \& Spindt, P. A. (2005). Wanna dance? How firms and underwriters choose each other. Journal of Finance, 60, 2437-2469.

Gande, A., Puri, M., \& Saunders, A. (1999). Bank entry, competition, and the market for corporate securities underwriting. Journal of Financial Economics, 54, 165-195.

Gasparino, C. (2005). Blood on the street: the sensational inside story of how wall street analysts duped a generation of investors. Free Press.

Heckman, J. J. (1979). Sample selection bias as a specification error. Econometrica, 47, 153-162.

Hong, H., \& Kubik, J. D. (2003). Analyzing the analysts: Career concerns and biased earnings forecasts. Journal of Finance, 58, 313-351.

Hong, H., Kubik, J. D., \& Solomon, A. (2000). Security analysts' career concerns and herding of earnings forecasts. RAND Journal of Economics, 31, 121-144.

James, C. (1992). Relationship-specific assets and the pricing of underwriting services. Journal of Finance, 47, 1865-1885.

Kallberg, J. G., Liu, C. H., \& Srinivasan, A. (2003). Dividend pricing models and REITs. Real Estate Economics, 31, 435-450.

Krigman, L., Shaw, W. H., \& Womack, K. L. (2001). Why do firms switch underwriters? Journal of Financial Economics, 60, 245-516. 
Lin, H., \& McNichols, M. F. (1998). Underwriting relationships, analysts' earnings forecasts and investment recommendations. Journal of Accounting and Economics, 25, 101-127.

Ljungqvist, A., Marston, F., \& Wilhelm, W. (2006). Competing for securities underwriting mandates: Banking relationships and analyst recommendations. Journal of Finance, 61, 301-340.

Ljungqvist, A., Marston, F., Starks, L., Wei, K., \& Yan, H. (2007). Conflicts of interest in sell-side research and the moderating role of institutional investors. Journal of Financial Economics, 85, 420-456.

Ljungqvist, A., Marston, F., \& Wilhelm, W. (2009). Scaling the hierarchy: How and why investment banks compete for syndicate co-management appointments. Review of Financial Studies, 22, 39774007.

Maddala, G. S. (1983). Limited dependent and qualitative variables in econometrics. Cambridge: Cambridge University Press.

Megginson, W. L., \& Weiss, K. A. (1991). Venture capitalist certification in initial public offerings. Journal of Finance, 46, 879-903.

Michaely, R., \& Womack, K. L. (1999). Conflict of interest and the credibility of underwriter analyst recommendations. Review of Financial Studies, 12, 653-686.

Mikhail, M. B., Walther, B. R., \& Willis, R. H. (1999). Does forecast accuracy matter to security analysts? The Accounting Review, 75, 185-200.

Murphy, K. M., \& Topel, R. H. (1985). Estimation and inference in two-step econometric models. Journal of Business and Economic Statistics, 4, 370-379.

O'Brien, P. C., \& Bhushan, R. (1990). Analyst following and institutional ownership. Journal of Accounting Research, 55-76, Supplement.

Puri, M. (1999). Commercial banks as underwriters: implications for the going public process. Journal of Financial Economics, 54, 133-163.

Staiger, D., \& Stock, J. H. (1997). Instrumental variables regression with weak instruments. Econometrica, 65, 557-586.

Stickel, S. E. (1992). Reputation and performance among security analysts. Journal of Finance, 47, 18111836.

Van De Ven, W., \& Van Pragg, B. M. S. (1981). The demand for deductibles in private health insurance. Journal of Econometrics, 17, 229-252.

Yasuda, A. (2005). Do bank relationships affect the firm's underwriter choice in the corporate-bond underwriting market? Journal of Finance, 60, 1259-1292. 